\title{
Market Sentiment and Firm Investment Decision-Making
}

\author{
Albert Danso $^{1}$; Theophilus Lartey ${ }^{1}$; Joseph Amankwah-Amoah ${ }^{2}$; Samuel Adomako ${ }^{3}$; Qinye Lu ${ }^{1}$; \\ Moshfique Uddin ${ }^{4}$
}

\section{Corresponding author: Albert.danso@dmu.ac.uk}

Note: Accepted version for publication in International Review of Financial Analysis

\begin{abstract}
While research on factors driving corporate investment decisions has blossomed, knowledge related to the Chief Executive Officer's (CEO's) market sentiment on investment decision outcomes is lacking. In this study, we extend the existing corporate finance literature by examining the underexplored issue of how CEOs' market sentiment drives firms' investment decisions. Capitalising on a large sample of US firms for the period 2004-2014, we uncovered some crucial observations. First, we found empirical support for our theoretical contention that market sentiment drives corporate investment decisions. Second, we established that, while financial flexibility induces managers to overinvest, the expectation of future profitability leads firms to underinvest during high sentiment periods. In addition, we uncovered that the 2007/08 financial crisis significantly impacted firm behaviour and realigned managerial decision-making. Thus, the sentiment-investment relationship is more pronounced during the crisis and the post-crisis periods. Our results are robust after accounting for the possibility of endogeneity and using alternative measures of both CEOs' market sentiment and firm investment.
\end{abstract}

Keywords: Market sentiment; investment; profitability; flexibility; crisis.

\section{Introduction}

Behavioural finance literature has argued that managerial decisions are affected by psychological

\footnotetext{
${ }^{1}$ Leicester Castle Business School, De Montfort University, UK.

${ }^{2}$ Kent Business School, University of Kent, UK.

${ }^{3}$ School of Management, University of Bradford, Bradford, UK.

${ }^{4}$ Leeds University Business School, Leeds, UK
} 
and/or cognitive biases (e.g. Baker et al., 2013; Ben-David et al., 2013; Malmendier et al., 2011). Building on this view, research in behavioural finance has highlighted how managerial behaviours drive corporate decisions. Principal among these encompass size premium (Lemmon \& Portniaguina, 2006), divergence from fundamental equity values (Shefrin, 2008; De Long et al., 1990), IPO underpricing and long-run returns (Boulton \& Campbell, 2016; Cornelli et al., 2006; Ljungqvist et al., 2006). However, while these studies reaffirm the broad relevance of managerial traits in driving corporate decision-making processes, the literature has failed to establish how market sentiment - decisionmakers' beliefs and feelings about a situation or event (Hribar et al., 2017) - drives corporate investment decision. In addition, our understanding relating to how this linkage is conditioned by financial flexibility, future profitability and financial crisis lacks theoretical precision.

Indeed, from the agency theoretical perspective, the influx of free cash flow and unused debt capacity influences managerial choices to invest more, consequently increasing investment distortions (Malmendier \& Tate, 2005; Stulz, 1990; Jensen, 1986). Similarly, the fix-price theory of investment (Kotlar et al., 2014; Precious, 1985; Malinvaud, 1980) stipulates that expected future profitability enhances willingness to increase investment in additional capacity towards meeting possible upward demand fluctuations (Greve, 2003). Such a condition is prevalent during high sentiment periods. On the other hand, the trade-off theory (DeAngelo et al., 2011) stresses that higher expected future profitability implies a generally low chance of financial distress (Fama \& French, 2002). Thus, such firms are able to access external financing for good future investment projects. Beyond these underpinnings, the issue of market sentiment in corporate decision-making is vitally important given that managers often have a comprehensive opinion on their firms' performance, customers, suppliers and industry dynamics. By developing and utilising networks with business leaders, politicians, academia and media, managers are able to gain a unique insight into the conditions in the industry in which their firms operate. These conditions are critical for strategic decision-making processes.

This study contributes to the finance literature in the following ways. First, we integrate the behavioural economics and finance disciplines with the social psychology literature. In doing so, we complement the literature exploring the relationship between managerial traits and corporate policies (e.g. Ho et al., 2016; Graham et al., 2013; Malmendier et al., 2011; Hackbarth, 2008). Thus, we enrich the literature by shedding light on managers' market sentiment as an indication of confidence in business, industry and economic fundamentals which drives firm investment levels. Second, we establish a financial flexibility perspective under which market sentiment leads a firm to overinvest during high sentiment periods. Financial flexibility decreases the firm's cost of capital, thereby reducing the competitive risk faced by the firm and the strategic benefit of unused debt capacity 
(O’Brien, 2003). Moreover, financially flexible firms have greater access to external capital markets to meet funding challenges arising from unanticipated earnings shortfalls and/or new growth prospects and hence avoid situations that may lead to suboptimal investment and poor performance (ArslanAyaydin et al., 2014). Similarly, the pecking order theory of capital structure stresses that firms accumulate financial slack to avoid the need for external funds in financing future investment opportunities (Myers 1984; Myers \& Majluf 1984), hence drawing the conclusion that firms maintain financial flexibility to avoid the costs of underinvestment (Froot et al., 1993). We therefore contend that financially flexible firms can secure cheaper financing (both free-cash and external debt financing) to make positive net present value (NPV) investments that otherwise lacked funding. This lowered cost of capital results in overinvestment which can also turn negative NPV investments into positive NPV projects.

Third, we also show that future profitability (the expectations perspective) plays an important role in the sentiment-investment relationship. The standard economic theory (see Bond et al., 2004) stresses that direct measures of expected future profitability significantly drive firm investment behaviour (Kotlar et al., 2014). Additionally, behavioural theory stipulates that firm profitability fundamentally drives firm investment decisions (Cyert \& March, 1963). Thus, we contend that, when firm profitability goals are expected to be achieved, managers tend to undertake adverse goals via decreasing investments. Hence, under the expectation of future profits, firms tend to underinvest.

Finally, strategic management distinctly places emphasis on the firm's competitive environment (Drnevich \& Kriauciunas, 2011; Ngah-Kiing Lim et al., 2009). A firm must find a balance or fit between the demands of its environment and its internal management systems in order to survive and succeed (Katsikeas et al., 2006; Pegels et al., 2000). Hence, by assessing the differential effect of sentiment on investment across the pre-crisis and post-crisis periods, we highlight the extent to which the 2007/08 financial crisis effects realigned managerial decision-making. We confirm that the most suitable management strategy and organisational structure for any given firm is a product of the specific set of environmental contingencies a firm faces (O'Brien et al., 2014; Acquaah, 2007). We therefore make contributions to complement these underpinnings.

The paper closest to our own is Gennaioli et al. (2016). They found that firm investment is impacted by Chief Financial Officers' (CFOs) expectations of earnings growth. However, among the limitations acknowledged in their work is the limited data and failure of their expectation measure to capture economic conditions. Our paper utilises a more plausible measure of sentiment that captures the manager's perspective in the US and contains the opinions of corporate chief executive officers on 
the state of the economy, their firm's profit expectations, market/demand growth, cost reduction, price increments and new technology improvements.

The rest of the paper is organised as follows: section 2 reviews the relevant literature and key theoretical underpinnings. Section 3 discusses the sample, empirical design and measurement of variables. Section 4 presents the regression results and discussion. Finally, section 5 provides a summary of the findings and outlines the practical implications.

\section{Literature}

\subsection{Theoretical perspective}

Agency theory confirms the premise of the rational choice theory by suggesting that agents are rational decision-makers whose goal is to maximise utility (Shapiro, 2005; Boudon, 1998; Simon, 1955). Nevertheless, extant psychology literature evidences that an individual's decision often deviates from this conventional paradigm (Ho et al., 2016; Graham et al., 2013; Malmendier et al., 2011; Hackbarth, 2008). Thus, in a survey of behavioural corporate finance literature, Baker et al. (2013) identified numerous managerial behavioural biases evidenced to influence corporate decisions. Key among these biases are managerial overconfidence and optimism (Malmendier et al., 2011; Heaton, 2002; Griffin \& Tversky, 1992). The managerial overconfidence theory postulates a 'better-than-average' effect under which overconfident individuals often overvalue their wisdom or skills beyond an average benchmark (Ho et al., 2016; Alicke, 1985; Svenson, 1981; Larwood \& Whittaker, 1977). Thus, their expectation of favourable future events is greater than the likelihood of occurrence, under the assumption that they possess more precise knowledge about future events.

An extension of the psychology literature to behavioural corporate finance proves that executives or managers are predominantly susceptible to exhibiting these behavioural biases, which consequently affects their decisions (Hirshleifer, 2015; Andriosopoulos et al., 2013; Landier \& Thesmar, 2009). Firstly, managers tend to demonstrate high degrees of confidence under the perception that outcomes are within their control (March \& Shapira, 1987). Secondly, they demonstrate higher optimism about uncertain outcomes when they assign higher degrees of commitment to the outcomes (Weinstein, 1980). Accordingly, managerial irrationality plays a central role in corporate financing behaviour. Following this reasoning, Parsons and Titman (2008) confirm that managerial preferences may have an impact on capital structures. Similarly, Bertrand and Schoar 
(2003) show that manager fixed effects significantly explain heterogeneity in firms' financial practices.

In keeping with the above, recent theoretical advances in finance literature confirm that managerial behavioural biases significantly affect investment and financing decisions (Ben-David et al., 2013; Campbell et al., 2011; Malmendier \& Tate, 2005, 2008; Shefrin, 2001). For instance, Shefrin (2001) postulates that overconfident and optimistic traits of managers affect their financing decisions. Following this reasoning, Hackbarth (2008) and Heaton (2002) introduced a theoretical model which proved that optimistic and/or overconfident managers tend to opt for a higher leverage level beyond what is optimal/rational. Hackbarth (2009) reports that overconfident managers feel their firm's equity is highly undervalued by the capital market and hence favour debt issuance to equity when seeking external finance.

\subsection{Empirical literature}

The question of whether and how management overconfidence and miscalibration impact corporate investment policies has also become a key strand in empirical corporate finance literature. Overconfident managers believe in their ability to generate higher returns on their investment projects, often leading to overinvestment (see Pikulina et al., 2017; Ben-David et al., 2013; Graham et al., 2013; Campbell et al., 2011; Goel \& Thakor, 2008; Malmendier \& Tate, 2005, 2008). Thus, they overvalue the returns of their investment projects and misperceive negative NPV projects as value creating (Kim et al., 2016). Malmendier et al. (2011) demonstrate that overconfidence induces managers to perceive their firms as being undervalued and thus perceive external financing, particularly equity, as overpriced. As such, managers utilise less external finance - and, in this case, equity - relative to their peers.

Malmendier and Tate (2005) stipulate that overconfident managers also have higher optimism regarding investment opportunities. Thus, they tend to overestimate the true value of their firm's equity. In another study, Malmendier and Tate (2008) report that overconfident managers undertake greater acquisitions under the assumption that firms are undervalued. Consequently, the market reactions for such managers are significantly adverse. Ferris et al. (2013) extended the managerial overconfidence literature to international mergers and acquisitions (M\&A) and found that overconfidence affects the number of manager's offers, the frequencies of non-diversifying and diversifying acquisitions, and the preference for cash to finance merger deals. Ben-David et al. (2013) also argue that managerial miscalibration drives numerous corporate finance activities. They argue that miscalibrated managers tend to invest more, utilise more debt, are more unlikely to pay dividends, and are more likely to repurchase shares, as well as use more long-term debt relative to short-term debt 
(Andriosopoulos et al., 2013). Hirshleifer et al. (2012) emphasise that overconfident managers tend to overvalue the net discounted expected payoffs from uncertain projects, either due to their universal expectation of favourable outcomes or due to the overestimation of their successful chances. They found that overconfident managers channel higher return volatility and higher investment in innovations, acquire more patents and patent citations, and achieve higher success in innovative research and developments.

In addition, Kim et al. (2016) argue that overconfident managers tend to overlook privately observed negative feedbacks. Consequently, negative NPV projects are maintained over time, leading to bad performance, which causes stock prices to crash. In addition, the overconfidence effect on crash risk is more pronounced when the manager is more dominant in the top management team and where there exist greater disparities of opinion among investors.

Other strands of literature have also proved that other managerial traits can significantly affect key corporate choices including capital structure (Cronqvist et al., 2012), innovation (Galasso \& Simcoe, 2011; Hirshleifer et al., 2012; Chen et al., 2015), financing choices (Dong et al., 2012), forecasting (Hribar \& Yang, 2016) and risk-taking attitude (Huang et al., 2016; Daniel \& Hirshleifer, 2015; Masulis \& Mobbs, 2011). Frank and Goyal (2007) demonstrate that manager characteristics significantly affect the variations in leverage across firms. Yim (2013) found a positive nexus between manager age and M\&A. Song and Thakor (2006) examine the motivations that induce a manager to provide inaccurate signals about proposed investment projects to the board. Hermalin and Katz (2000) introduced a framework under which a manager has incentives to prefer less informative regimes than would be desired by firm owners (shareholders). Indeed, existing literature has demonstrated that firm investment decisions may be influenced by investor sentiment (Arif \& Lee, 2014). Thus, higher investor sentiment leads to overinvestment in capital expenditures via overestimation of future cash flows from investments. This consequently destroys firm value and, consistent with business cycle literature, weakens future stock returns (Arif \& Lee, 2014). Gennaioli et al. (2016) and Kothari et al. (2016) also found that managers are extrapolative and slow in updating their expectations regarding past-year earnings and returns, which consequently slows down their responses. As such, managers may begin to respond by making plans to cut investments after observing the past year's negative earnings surprises and low stock returns, but the actual decline in investment occurs two years after due to the investment lags. Along similar lines, Lee et al. (2018) reported that managerial ability impacts investment positively, particularly for highly financially flexible firms.

Rather than using investor sentiment, our paper employs CEOs' sentiment and argues that 
manager sentiment affects a firm's investment choices in three ways. First, market sentiment impacts on firm investment when managers incorporate future profit levels into their strategic decisions. Second, under high or positive sentiment periods, financially flexible firms can secure both cheaper internal and external debt financing to make positive NPV investments that otherwise lacked funding. This lowered cost of capital can, however, drive high levels of investment, particularly negative NPV projects. Third, when economic conditions are positive, as observed before the crisis, managers perceive that the positive state will continue and thus undertake high investments without incorporating the economic outlook (Grout \& Zalewska, 2016; Vortelinos, 2016; Cohen et al., 2014). A fundamental increase in market sentiment post-crisis, however, increases demand for loanable funds, consequently increasing the total level of investment under high monitoring (Bhimjee et al., 2016).

\section{Data and Methodology}

Our study is based on a large sample of US firms whose balance sheet and income statements were obtained from the merged Center for Research in Security Prices (CRSP)/Compustat database for the period 2004 to 2014. In addition to this, the managerial sentiment data was obtained from the Conference Board Measure of CEO Confidence Survey. In all, a total number of 76,166 firm-year observations were used in this study.

\subsection{Measurement of variables}

\subsubsection{Firm investment}

Following the extant literature (e.g. Dang 2011; Aivazian et al., 2005), our dependent variable (investment-INVI) is measured as the ratio of net capital expenditure (capital expenditure minus depreciation) of firm $i$ to the book value of total property, plant and equipment for the current year. As a robustness check, we also used two additional measures of firm investment. These are (a) Investment 2 (INV2), the ratio of total capital expenditure of firm i to the book value of total property, plant and equipment for the current year (Chava \& Roberts, 2008); and (b) Investment 3 (INV3), the ratio of net capital expenditure (capital expenditure minus depreciation) of firm $i$ to book value of total assets for the current year (Firth et al., 2008).

\subsubsection{Market sentiment}

In line with the existing literature (e.g. Delis et al., 2014; Bachmann \& Sims, 2011; Best, 2008), the Conference Board's quarterly measure of CEO Confidence Survey was used as our instrument to 
gauge market sentiment. This survey has been available at a quarterly frequency since 1976. This sentiment data encompasses the responses of CEOs from 10 industrial sectors that span the economic activity of the US. These sectors are manufacturing of non-durables - (i) food, textiles and apparel; (ii) paper, printing, publishing; (iii) chemicals, petroleum and rubber; manufacturing of durables - (iv) metal; (v) machinery; and services - (vi) utilities; (vii) wholesale and retail trade; (viii) banking and financing; (ix) insurance; (x) business services. The survey contains four questions to gauge the following: current (i) economic conditions compared to six months ago, (ii) conditions in the specific industry to which each CEO belongs compared to six months ago; and expectations about (iii) the economy six months ahead and (iv) the specific industry six months ahead. The available answers are classified and weighted numerically as substantially better $(=100)$, moderately better $(=75)$, same $(=50)$, moderately worse $(=25)$ and substantially worse $(=0)$. To compute the primary sentiment value, the values of the answers to questions one through three are averaged into a number ranging from 0100. Lower values of this index reflect poor market sentiment (or higher CEO anxiety) (Delis et al., 2014).

The survey also includes two supplementary questions, which are totalled, averaged and reported as a separate headline number for each industry and aggregately. These two supplementary questions with their respective answer choices are: (1) What are your firm's profit expectations for the next 12 months? Answer choices: (i) increase substantially; (ii) increase moderately; (iii) remain the same; (iv) decrease; and (2) If you expect profits to increase, which do you foresee as the prime source of improvement? Answer choices: (i) market/demand growth; (ii) cost reduction; (iii) price increase; (iv) new technology. Inherently, high confidence among industry executives indicates that money can be more confidently invested in firms belonging to that industry and vice versa.

Indeed, the survey data serves as the closest attempt to capture the manager's perspective in the US and contains the opinions/sentiment of high-level corporate executive officers on the state of the economy, their firm's profit expectations, market/demand growth, cost reduction and price increments, as well as new technology improvements. In addition to this, the survey has proven to have important predictive power, helping to forecast macroeconomic indicators (e.g. GDP, interest rates, etc.) even after controlling for a host of factors (see Shapiro et al., 2018; Levanon, 2010; ; Medoff et al., 2004; Souleles, 2004; Carroll et al., 1994).

\subsubsection{Control variables}

In line with other empirical studies (Firth et al., 2008; Aivazian et al., 2005a, b), we controlled for other variables that are likely to affect firm investment. These variables include firm size, asset 
tangibility, non-debt tax shield, return on assets, firm growth, dividend, earnings volatility. To determine whether sentiments are driven by correlations of systematic or idiosyncratic returns, we disaggregate the stock returns to a systematic component and an idiosyncratic component by applying the standard CAPM model (Vendrame et al., 2016; Panousi \& Papanikolaou, 2012). Descriptions of all the variables used are presented in Table 1.

\section{[Table 1 about here]}

\subsection{Estimation method}

In this section, we model the empirical relationship between market sentiment and firm investment. Specifically, we employed the following econometric framework:

$$
\text { Investment }_{i, t}=\alpha+\beta \text { market Sentiment }{ }_{i, t}+\beta X_{i, t}+\omega_{i}+\mu_{t}+\varepsilon_{i, t}
$$

Where $i$ denotes the $i$ th firm and $t$ denotes fiscal year. Investment is the measure of firm-level investment as defined in Table 1, market sentiment is the measure of business, industry and economic outlook by year $t, \mathrm{X}$ is the vector of the control variables employed in our analysis, $\alpha$ and $\beta$ are parameters, $\omega_{i}$ is a firm fixed effect, and $\mu_{t}$ is a year fixed effect. The model can be estimated using OLS; however, this approach may cause biases and inconsistent estimates due to correlation of the firm fixed effects with the explanatory variables (Wooldridge, 2009). Hence, we estimated these models using the panel fixed effects approach and use pooled OLS only for a robustness check. We controlled for time fixed effects by including time dummies in all estimations. In order to control for possible heteroscedasticity and autocorrelation within firms, the estimated standard errors of the regression coefficients are clustered at the firm level. In line with Jiang et al. (2018), all sentiment indexes are standardised to have zero mean, unit variance and higher values for higher sentiment levels. All continuous variables are winsorised at their 1st and 99th percentiles to mitigate the effect of outliers (Fosu et al., 2016; Dudley, 2012). Finally, to deal with potential reverse causality between dependent and independent variables, we followed the existing literature (e.g. Danso et al., 2019; Danso \& Adomako, 2014; Zou and Xiao, 2006) and lag the explanatory variables by one period. A summary of the key variables used in our main analyses and their descriptions are reported in Table 1. 


\section{Results and Discussion}

\subsection{Descriptive statistics and bivariate correlations}

\section{[Table 2 about here]}

\section{[Table 3 about here]}

The descriptive statistics of the variables for our empirical analysis are presented in Table 2. Our three (3) measures of firm investment have mean values of $-0.07,0.28$ and 0.00 . These variables also have a standard deviation of $0.34,0.28$ and 0.05 , respectively. In general, our measures of firm investment show a low level of variability. Further, the mean value of our main sentiment variable (MSent) is 0.54 with a standard deviation of 0.08 . This variable rises from a minimum of 0.35 to a maximum of 0.67 , suggesting a fair or moderate degree of heterogeneity across the firms investigated. With regards to the control variables, a few findings are worth noting. First, we observed that the mean value of Size (SIZ) is 5.34 with a standard deviation of 2.52. SIZ has a minimum and maximum value of 0.47 and 9.75, respectively, signifying a high degree of heterogeneity. Also, the average value of the ROA is 0.04 and has a standard deviation of 0.23 . This variable also has a minimum value of -0.65 and a maximum value of 0.32 , suggesting that some of the firms investigated experienced negative returns during the period of investigation. In Table 3, we present the correlation between all the variables used in this study. In general, the evidence obtained from the correlation matrix, as well as the descriptive statistics, suggests that our sample does not seem to suffer from any serious issues such as multicollinearity, limited variation and heterogeneity or large outliers.

\subsection{Market sentiment and investment}

In Table 4, we present the empirical results of our baseline model by testing the effect of market sentiment on firm investment ( $I N V 1)$, which is our main measure of our dependent variable. Two main estimation methods are used, OLS and fixed effects (hereafter FE). Models $1 \& 2,5 \& 6$ and $9 \& 10$ are based on FE and the rest are OLS. The interpretation of the findings is based on the fully specified FE. The OLS is used as a robustness check. Also, models $1-4$ are based on our main measure of investment (INVI) as defined in Table 1. Models 5 to 12 are used as robustness checks. The discussion starts with Model 2 where market sentiment (MSent) is positively and significantly related to firm investment (INV1). The coefficient of this variable is 0.616 and has a standard deviation of 0.08 . This suggests that a one standard deviation increase in manager sentiment is associated with a $4.93 \%$ increase in firm investment. 


\section{[Table 4 about here]}

We confirm the findings of the positive relationship between market sentiment and firm investment by using alternative measures of investment (i.e. INV2 and INV3) as defined in Table 1. Across all the models, MSent is positive and statistically significant at the $1 \%$ level. Overall, our findings are consistent with the view that market sentiment is an indication of business and economic conditions (e.g. Bachmann \& Sims, 2011; Delis et al., 2014) and thus driving the investment decisions of their firms.

\subsection{Robustness checks}

\section{[Table 5 about here]}

\section{[Table 6 about here]}

\section{[Table 7 about here]}

The analysis above consistently shows that market sentiment drives corporate investment. In this section, we further examine if our results are robust to alternative sentiment measures and econometric method. From Tables 5 to 7, we demonstrate that our results are robust to using the Small Business Optimism Index (SBOpt), Michigan Sentiment Index (UCSent) and the Chicago Board Options Exchange Volatility Index (VIX) (as alternative measures of sentiment) on all the three measures of investment. We note that the coefficient of sentiment (on SBOpt, UCSent and VIX) is positive and statistically significant at the $1 \%$ level on all models with controls, thus also suggesting that market sentiment increases firm investment. Further, in Table 8 we again estimate our main models by adopting a 2-step Generalised Method of Moments (GMM) estimation approach (Blundell \& Bond, 1998) to address any endogeneity issues. Given the relatively large dataset used in our study, we report 2-step estimation results with GMM standard errors. Evidence obtained from our GMM results shows that the signs and the magnitude of the coefficient of our independent variable (MSent) remain similar to what is already reported in Table 4 (i.e. positive and significant at the $1 \%$ level). Generally, the results obtained from the GMM estimation suggest that the findings are not plagued by endogeneity problems and that the main results reported in Table 4 are robust to an alternative econometric model.

\section{[Table 8 about here]}




\subsection{Sentiment and investment - the role of financial flexibility}

\section{[Table 9 about here]}

The evidence presented above indicates that market sentiment leads a firm to increase investment. However, an additional mechanism through which market sentiment might lead a firm to increase investment is underpinned by the two conventional paradigms for investment distortions: manager-shareholders' conflict of interests (Jensen \& Meckling, 1976) and asymmetric information between managers and lenders (Myers \& Majluf, 1984). These paradigms drive investment to be sensitive to firms' free cash flow (see Jensen, 1986; Stulz, 1990). By the agency theory, managers tend to overinvest in order to secure private benefits (e.g. 'perks', incentives, large empires, entrenchments, etc.) (Malmendier \& Tate, 2005). Because external capital market restrictions mitigate the degree of managers' self-centred investment, an influx of free cash flow increases their choices to invest more, consequently increasing investment distortions (Jensen, 1986). Thus, excessive free cash flow drives high investments (particularly negative NPV projects) (Richardson, 2002; Blanchard et al., 1994). Contrarily, with limited free cash flows, overinvestment is mitigated given that firms are induced to raise funds via external capital markets characterised by enhanced monitoring (Richardson, 2006). Similarly, under asymmetric information, managers in performing their fiduciary role limit external financing primarily to avoid diluting the firms' (undervalued) shares/ownership. Under such a scenario, free cash flow increases investment, but mitigates distortions (Fazzari et al., 1988). Thus, following these arguments, financial flexibility may bias our finding of a positive sentimentinvestment nexus. We conduct several tests to assess whether financial flexibility could confound our sentiment-investment inferences.

In Table 9, we augment our baseline specification regressing firm investment on the market indicator to control for financial flexibility. Following Arslan-Ayaydin et al. (2014), we used the median values of cash holdings and leverage ratios to initially generate four subsamples of firms: (i) low leverage (LL); (ii) high leverage (HL); (iii) low cash (LC); and (iv) high cash (HC) firms. In addition, two more robust groupings of firms were incorporated by merging the policy specification simultaneously: (v) low leverage and high cash (LL-HC); and (vi) high leverage and low cash (HLLC) firms. Panel A reports the results for the simplified groupings while Panel B shows the more 
robust combinations.

Following the grouping of firms into flexible and less flexible subsamples, our results indicate that financial flexibility does not confound the significant nexus between the market sentiment indicator and firm investment. Nevertheless, the estimated impact (measured by the size of the coefficients) of the market sentiment indicator on firm investment indicates that flexibility does affect the sensitivity of the sentiment-investment nexus. For low cash flow (LC) and high leverage (HL) (implying less financial flexibility) firms, the estimated sentiment-investment coefficient declined. However, for high cash flow (HC) and low leverage firms (LL) (implying high financial flexibility), the estimated sentiment-investment coefficient increased. In terms of economic significance, while the sentiment-investment coefficient for LC and HL firms drops from 0.604 (main result in Table 4) to 0.451 and 0.411 respectively, that of HC and LL firms rises to 0.774 and 0.985 respectively. This finding implies that an influx of free cash flow and unused debt capacity intensifies managers' choices to invest more during high sentiment periods, which may consequently increase investment distortions. Contrarily, under conditions of limited free cash flow and used debt capacity, overinvestment is mitigated during high sentiment periods given that firms are induced to raise funds via external capital markets characterised by enhanced monitoring.

\subsubsection{Financial flexibility by low leverage and high cash balances}

Despite its valuable insights, the analysis so far can be misleading given that it is based on a univariate setting and considers the cash and leverage positions of firms distinctly to group firms into different groups. However, firm cash holdings and leverage choices are strongly interrelated (e.g. pecking order theory (POT) - Arslan-Ayaydin et al., 2014; Fama \& French, 2002; Titman \& Wessels, 1988). In this sense, an adjustment in one policy variable leads to an adjustment in the other policy variables (see Gatchev et al., 2010). Thus, firms may opt to achieve financial flexibility via both high cash flow and low leverage policies simultaneously. Following this reasoning, we augmented our firm groupings on the basis of both policies: high cash flow-low leverage (HCLL) versus low cash flowhigh leverage (LCHL) firms. The findings as reported in panel B of Table 9 confirm our observation above that highly flexible firms (HCLL) have a higher likelihood of overinvesting relative to low flexibility firms (LCHL). Highly flexible firms possess sufficient internal funds and unused debt capacity for investments. They also undergo fewer disciplinary or monitoring mechanisms by the capital market or corporate governance, and thus they overinvest. The result confirms the position of Myers and Majluf (1984) that liquid financial assets (slack) can mitigate the underinvestment biases. However, the combined effect of an influx of free cash flow and incomplete shareholder monitoring 
causes manager-shareholder agency problems (Vogt, 1994). Consequently, managers develop the tendency to overinvest (particularly in negative-NPV projects) (Jensen and Meckling, 1976). Where firms lack sufficient internal funds and debt capacity, they are reluctant to issue new equity due to perceived stock undervaluation by the market. Thus, low flexibility firms restrict their investment during high sentiment periods characterised by good economic and business signals.

\subsection{Sentiment and investment - the role of future profitability}

\section{[Table 10 about here]}

The evidence presented above indicates that financial flexibility strengthens the sentimentinvestment nexus. However, an additional mechanism through which market sentiment might lead a firm to increase investment is underpinned by standard economic theory (see Bond et al., 2004), which stresses that direct measures of expected future profitability significantly drive the behaviour of firm investment (Kotlar et al., 2014). Moreover, behavioural theory stipulates that a fundamental driver of investment decisions is profitability (Cyert \& March, 1963). Thus, when firm profitability goals remain unachieved, managers tend to undertake adverse goals via increasing investments (Fiegenbaum et al., 1996; Kahneman \& Tversky, 1979). The fix-price theory of investment (Driver et al., 2005; Lambert \& Mulkay, 1987; Precious, 1985; Malinvaud, 1980) also argues that profitability plays a key role particularly due to demand uncertainty, a condition prevalent during high sentiment periods. Higher future profitability enhances willingness to increase investment in additional capacity towards meeting possible upward fluctuations in demand (Bhaskar \& Glyn, 1995). The trade-off theory (e.g. DeAngelo et al., 2011) also stipulates that higher expected future profitability implies a generally low chance of financial distress (Fama \& French, 2002) to support external financing for good future investment projects (positive NPV projects). Thus, following these arguments, higher expected future profitability may bias our finding of a positive sentiment-investment nexus. We conducted several tests to assess whether higher expected profitability could confound our sentiment-investment inferences.

In Table 10, we augmented our baseline specification regressing firm investment on the managerial indicator to control for future profitability. Specifically, we included not only the current value, but also one-year, two-year and three-year leads of the profitability measure, and conducted separate analyses using two alternative profitability measures: Profit margin (the sum of pre-tax income, interest expense, and depreciation and amortisation divided by sales) and Return on assets (operating income before depreciation scaled by total assets). All 'odd numbered' models (1, 3, 5, 7, 
9 and 11) are without controls and all regressions incorporate firm fixed effects. We found that the significant nexus remains unconfounded between the three investment measures and the market sentiment indicator. Nevertheless, the estimated impact (measured by the size of the coefficients) of the market sentiment indicator on all three measures of firm investment declined after controlling for future profitability (comparing against the main result in Table 4 without future profitability controls), thus implying that expectation of future profitability causes firms to underinvest in the current year relative to low flexibility firms. Hence, although market sentiment continues to have a significant impact on firm investment, firms tend to underinvest when managers incorporate future profit levels into their strategic decisions.

\subsection{Sentiment and investment - the joint effect of financial flexibility-future profitability}

\section{[Table 11 about here]}

Despite the valuable insights above, the analysis so far has emphasised a univariate setting and considered the firm financial flexibility and future profit expectations separately. However, firm financial flexibility and future profit expectations are strongly interrelated. Vogt (1994) evidenced that Jensen's (1986) free cash flow and Myers and Majluf's (1984) POT provide probable explanations for the profitability-cash flow-investment nexus. Implicit in POT are two crucial assumptions about managers. First, information asymmetries - the probability that managers have better information about the firm's current earnings and future growth opportunities relative to outsiders, thus motivating a strong desire to protect such proprietary information (Dang et al, 2014; Guney \& Fairchild, 2011). High reliance on internal funds therefore prevents managers from publicly disclosing information about the firm's investment opportunities and the potential profits to be realised from investing in them (Myers, 1984). Second, in performing their fiduciary duties managers will aim at maximising shareholders' interests (Ebrahim et al., 2014). Under such a scenario, managers may even forgo positive-NPV projects where they require equity issuance and result in a dilution of firm ownership (Myers \& Majluf, 1984). Because a highly profitable firm has greater financial slack, highly liquid assets (cash and marketable securities) plus any unused debt capacity, it may have no incentive to issue debt or equity to fund most, if not all, of its investment opportunities (Zona, 2012; Tucker \& Stoja, 2011; Kim et al., 2008). Following this reasoning, prudent managers will attempt to retain financial flexibility and at the same time ensure the long-term survivability of their firms. An adjustment in one 
policy variable leads to an adjustment in the other policy variables. Thus, controlling for the two conditions should enhance the robustness of our earlier findings.

Thus, in this section, we augmented our baseline specification regressing firm investment on the managerial indicator and controlled for both financial flexibility and future profitability. The findings as reported in Table 11 reveal that controlling for both variables does not confound the significant relationship between the market sentiment indicator and firm investment. Nevertheless, we observe that, to mitigate information asymmetries, the investment-sentiment sensitivity is greater for high financial flexibility firms (HC and LL in Panel A). This result is further confirmed by our robust groupings in Panel B - high flexibility firms (HCLL). Thus, the strong desire to protect proprietary information about the firm's investment opportunities and the potential profits to be realised from investing in them motivates a high reliance on free cash flows/flexibility during high sentiment periods. When profitable firms retain their earnings/profits as equity and build up cash reserves, they create the financial slack. This allows financial flexibility and, ultimately, firm investment and long-term survival.

\subsection{Financial crisis and the sentiment-investment relationship}

Did the 2008 global financial crisis affect firm behaviour? Two key strands of literature examine this hypothesis. The first strand, grounded on the financial constraints theory (shocks to credit markets), articulates that the financial crisis worsened credit market conditions (i.e. the quantity of credit available declined while borrowing costs increased) (see Ivashina \& Scharfstein, 2010; Fazzari, Hubbard \& Petersen, 1988; Stiglitz and Weiss, 1981). Accordingly, firms responded by cutting capital expenditures, reducing debt issuance, drawing down lines of credit and substituting internal liquidity for external liquidity (see Campello et al., 2010; Duchin et al., 2010). The second strand, however, articulates that firm behaviour during the crisis was not always explained by the financial constraints theory. Instead, firms responded directly to the weakening demand (Kahle \& Stulz, 2013; Paunov, 2012) and to risk (Kahle \& Stulz, 2013). Duchin et al. (2010) demonstrated that firm investment dropped significantly following the onset of the crisis. Particularly, the drop was more prominent for firms characterised by fewer internal financial resources - cash reserve and net short debt, thus confirming the theory of investment under financial constraints and capital market imperfections (Bo et al., 2014).

Thus, in this subsection, we build on our baseline model presented in Table 4 and empirically test whether the 2007/08 crisis impacted on the sentiment-investment nexus for US firms. To do this, we split our data into three sample periods (i.e. pre-crisis, crisis and post-crisis) and re-estimate the 
regression models. We present the results in Table 12.

\section{[Table 12 about here]}

We found that, generally, the impact of market sentiment on investment has been significantly driven by the financial crisis effects. The subsample relationship and statistical significance appear dissimilar across the three sample periods. For instance, the effect of MSent on investment remains insignificant in the pre-crisis period, thus giving confirmation of our hypothesis that, when economic conditions are positive, as observed before the crisis, managers underestimate the riskiness of their investments and also perceive that the positive state will continue. As such, they undertake high investments irrespective of the prevailing risks.

However, we observed that the coefficient remains positive and significant across the two remaining sampling periods - though the impact of market sentiment on investment appears larger and more significant in the post-crisis period than in the crisis period. The state of economic conditions manifested during the crisis and thus managers began factoring these conditions into their investment decisions (Bo et al., 2014). Following robust regulations over the period, the post-crisis period envisaged a further enhancement in the sentiment-investment nexus where a fundamental increase in market sentiment increases demand for loanable funds, consequently increasing the total level of investment under high monitoring and discipline. Thus, there was a more strengthened sentimentinvestment nexus post-crisis. In general, the evidence observed suggests that market sentiment and firm investment relationship show varied levels of sensitivity to the 2007/08 financial crisis.

\subsubsection{The financial flexibility implications during the financial crisis}

Despite the valuable insights above which stressed that highly flexible firms (HCLL) have a higher likelihood of overinvesting relative to low flexibility firms (LCHL), given that an influx of free cash flow and unused debt capacity intensifies managers' choices to invest more during high sentiment periods, we extend this argument to explore whether there is evidence of this contention during the 2008/09 crisis period versus the pre-crisis and post-crisis periods when the economy is normal. The findings as reported in Table 13 confirm our hypothesis that highly flexible firms have a higher likelihood of overinvesting more during high sentiment periods relative to low flexibility firms. The subsample relationship and statistical significance appear significant for HCLL firms during the precrisis (at the 5\% level) and post-crisis (at the 1\% level). Although LCHL firms recorded an insignificant coefficient during the pre-crisis period, the coefficient was significant (at the $1 \%$ level) during the post-crisis period, which indicates that fundamental increases in market sentiment increase 
demand for loanable funds particularly for all firms, consequently increasing their total level of investment. Nevertheless, the influx of free cash flow and unused debt capacity in HCLL firms intensifies managers' choices to invest more during high sentiment periods, which may consequently increase investment distortions.

Further, given that the state of economic conditions manifested during the financial crisis - a period characterised by high uncertainties, weak business signals and firm failures (AmankwahAmoah, 2016; Iwasaki, 2014; Kahle and Stulz, 2013; Paunov, 2012) - managers factored these conditions into their investment decisions (Bo et al., 2014). We observe that low flexibility firms overinvested during the crisis period perhaps to enhance their ability to survive and overcome the adverse effects of the crisis. Highly flexible firms, however, reduced investments during the crisis period, hence indicating that, when economic conditions are poor, as observed during the crisis, managers of HCLL firms overestimate the riskiness of their investments while perceiving a long persistence of the negative state. As such, they reduce their investments in line with the prevailing risks. Overall, the evidence confirms that HCLL firms overinvest during high sentiment periods.

\section{[Table 13 about here]}

\subsubsection{The future profitability implications during the financial crisis}

The evidence presented earlier indicates that expectation of future profitability causes firms to underinvest relative to low flexibility firms. In this section, we augment our analysis in Table 10 to empirically test whether the 2007/08 crisis had implications for the profitability role on the sentimentinvestment nexus for US firms. In line with the findings in Table 12, we found evidence confirming that, generally, the implications on the nexus have been significantly driven by the financial crisis effects. The subsample relationship and statistical significance appear dissimilar across the three sample periods. Taking future profitability into consideration, the effect of MSent on investment is insignificant in the pre-crisis period, thus giving confirmation of our hypothesis that, when economic conditions are positive, as observed before the crisis, managers undertake investments irrespective of the prevailing risks. However, we observed that the coefficient remains economically significant across the two remaining sampling periods - though the impact of CEOs' market sentiment on investment appears larger and more significant in the post-crisis period (at the $1 \%$ level) than in the crisis period (at the 5\% level). The estimated impact (measured by the size of the coefficients in the even number models of Table 14 - with other firm controls) of the market sentiment indicator on firm investment under all subsamples declined after controlling for future profitability relative to the result 
in Table 12 (models 1, 4 and 7 - without future profitability controls). This finding particularly holds for the post-crisis period following robust regulations over the period. In general, the evidence observed suggests that the implications of future profitability on the market sentiment and firm investment nexus show varied levels of sensitivity to the 2007/08 financial crisis. Although market sentiment continues to have a significant impact on firm investment, firms tend to underinvest when managers incorporate future profit levels into their strategic decisions particularly during the postcrisis period.

\section{[Table 14 about here]}

\section{Conclusion and Implications}

In this article, we examined the relationship between CEOs' market sentiment and investment using a sample of US firms. Our key arguments are rooted in the behavioural finance literature that contends that market sentiment is an important driver of firms' investment decisions. In particular, we observed that the sentiment-investment relationship is significant and positive across all our models, even after dealing with possible endogeneity issues. We show that the impact of sentiment on investment is more significant in the crisis and the post-crisis periods than in the pre-crisis period. However, we found no evidence to indicate that financial flexibility matters in the sentiment-investment relationship. Indeed, our results are robust to different measures of both the dependent and the independent variables as well as the different econometric methods.

Moreover, our results offer support for the role of psychological and/or cognitive biases in influencing the corporate decisions of firms. We also report strong evidence of the role of future profitability in the sentiment-investment nexus although firms tend to underinvest. We further observed that financial flexibility motivates firm overinvestment during high sentiment periods. We also found that the sentiment-investment relationship tends to be more pronounced in the crisis and post-crisis periods. Taken together, the overall evidence obtained suggests that market sentiment is imperative to the investment level of the firm.

From a practical standpoint, our study's findings indicate that market sentiment can be a valuable asset in driving firms' investment decisions. The effect of sentiment on investment is amplified when there is an influx of free cash flow and unused debt capacity. In this way, excess cash flow reinforces the sentiment-investment relationship as it intensifies the manager's choice to invest 
more during high sentiment periods.

Notwithstanding these useful findings, it is important to recognise a key potential limitation of this study. Specifically, we only looked at one country (the US) and there is the possibility that the findings obtained are specific to this setting and not to other settings - especially developing and emerging economies. Thus, more broad-based studies focusing on these countries could be looked at in future research. Future studies could also explore whether these findings about market sentiment might hold in the different cultural and institutional contexts of developing nations in Latin America, Asia and Africa.

\section{References}

Aivazian, V. A., Ge, Y., \& Qiu, J. (2005a). Debt maturity structure and firm investment. Financial Management, 34(4), 107-119.

Aivazian, V. A., Ge, Y., \& Qiu, J. (2005b). The impact of leverage on firm investment: Canadian evidence. Journal of Corporate Finance, 11(1-2), 277-291.

Alicke, M. D. (1985). Global self-evaluation as determined by the desirability and controllability of trait adjectives. Journal of Personality and Social Psychology, 49(6), 1621.

Amankwah-Amoah, J. (2016). An integrative process model of organisational failure. Journal of Business Research, 69(9), 3388-3397.

Andriosopoulos, D., Andriosopoulos, K., \& Hoque, H. (2013). Information disclosure, CEO overconfidence, and share buyback completion rates. Journal of Banking \& Finance, 37(12), 5486-5499.

Arif, S., \& Lee, C. M. (2014). Aggregate investment and investor sentiment. The Review of Financial Studies, 27(11), 3241-3279.

Arslan-Ayaydin, Ö, Florackis, C., \& Ozkan, A. (2014). Financial flexibility, corporate investment and performance: Evidence from financial crises. Review of Quantitative Finance and Accounting, 42(2), $211-$ 250.

Bachmann, R., \& Sims, E. R. (2011). Confidence and the Transmission of Government Spending Shocks, National Bureau of Economic Research. (No. w17063).

Baker, M., \& Wurgler, J. (2013). Behavioral corporate finance: An updated survey. Handbook of the economics of finance (pp. 357-424) Elsevier.

Ben-David, I., Graham, J. R., \& Harvey, C. R. (2013). Managerial miscalibration. The Quarterly Journal of Economics, 128(4), 1547-1584.

Bertrand, M., \& Schoar, A. (2003). Managing with style: The effect of managers on firm policies. The Quarterly Journal of Economics, 118(4), 1169-1208.

Best, R. J. (2008). CEO confidence and stock returns. International Journal of Business Research, 8(3), 113117.

Bhaskar, V., \& Glyn, A. (1995). Investment and profitability: The evidence from the advanced capitalist countries. Macroeconomic Policy After the Conservative Era, 175-196. 
Bhimjee, D. C., Ramos, S. B., \& Dias, J. G. (2016). Banking industry performance in the wake of the global financial crisis. International Review of Financial Analysis, 48, 376-387.

Blanchard, O. J., Lopez-de-Silanes, F., \& Shleifer, A. (1994). What do firms do with cash windfalls? Journal of Financial Economics, 36(3), 337-360.

Blundell, R., \& Bond, S. (1998). Initial conditions and moment restrictions in dynamic panel data models. Journal of Econometrics, 87(1), 115-143.

Bo, H., Driver, C., \& Lin, H. M. (2014). Corporate investment during the financial crisis: Evidence from china. International Review of Financial Analysis, 35, 1-12.

Bond, S. R., Klemm, A., Newton-Smith, R., Syed, M., \& Vlieghe, G. W. (2004). The roles of expected profitability, Tobin's Q and cash flow in econometric models of company investment. Bank of England Working Paper No. 222

Boudon, R. (1998). Limitations of rational choice theory. American Journal of Sociology, 104(3), 817-828.

Boulton, T. J., \& Campbell, T. C. (2016). Managerial confidence and initial public offerings. Journal of Corporate Finance, 37, 375-392.

Campello, M., Graham, J. R., \& Harvey, C. R. (2010). The real effects of financial constraints: Evidence from a financial crisis. Journal of Financial Economics, 97(3), 470-487.

Campbell, T. C., Gallmeyer, M., Johnson, S. A., Rutherford, J., \& Stanley, B. W. (2011). CEO optimism and forced turnover. Journal of Financial Economics, 101(3), 695-712.

Carroll, C. D., Fuhrer, J. C., \& Wilcox, D. W. (1994). Does consumer sentiment forecast household spending? if so, why? The American Economic Review, 84(5), 1397-1408.

Chava, S., \& Roberts, M. R. (2008). How does financing impact investment? the role of debt covenants. The Journal of Finance, 63(5), 2085-2121.

Chen, Y., Podolski, E. J., \& Veeraraghavan, M. (2015). Does managerial ability facilitate corporate innovative success? Journal of Empirical Finance, 34, 313-326.

Cohen, L. J., Cornett, M. M., Marcus, A. J., \& Tehranian, H. (2014). Bank earnings management and tail risk during the financial crisis. Journal of Money, Credit and Banking, 46(1), 171-197.

Cornelli, F., Goldreich, D., \& Ljungqvist, A. (2006). Investor sentiment and pre-IPO markets. The Journal of Finance, 61(3), 1187-1216.

Cronqvist, H., Makhija, A. K., \& Yonker, S. E. (2012). Behavioral consistency in corporate finance: CEO personal and corporate leverage. Journal of Financial Economics, 103(1), 20-40.

Cyert, R. M., \& March, J. G. (1963). A behavioral theory of the firm. Englewood Cliffs, NJ, 2, 169-187.

Dang, V. A. (2011). Leverage, debt maturity and firm investment: An empirical analysis. Journal of Business Finance \& Accounting, 38(1-2), 225-258.

Dang, V. A., Kim, M., \& Shin, Y. (2014). Asymmetric adjustment toward optimal capital structure: Evidence from a crisis. International Review of Financial Analysis, 33, 226-242.

Daniel, K., \& Hirshleifer, D. (2015). Overconfident investors, predictable returns, and excessive trading. Journal of Economic Perspectives, 29(4), 61-88.

Danso, A., Lartey, T., Fosu, S., Owusu-Agyei, S., \& Uddin, M. M. (2019). Leverage and firm investment: The role of information asymmetry and growth. International Journal of Accounting and Information Management, 
Danso, A., \& Adomako, S. (2014). The financing behaviour of firms and financial crisis. Managerial Finance, 40(12), 1159-1174.

De Long, J. B., Shleifer, A., Summers, L. H., \& Waldmann, R. J. (1990). Noise trader risk in financial markets. Journal of Political Economy, 98(4), 703-738.

DeAngelo, H., DeAngelo, L., \& Whited, T. M. (2011). Capital structure dynamics and transitory debt. Journal of Financial Economics, 99(2), 235-261.

Delis, M. D., Kouretas, G. P., \& Tsoumas, C. (2014). Anxious periods and bank lending. Journal of Banking \& Finance, 38, 1-13.

Dong, M., Hirshleifer, D., \& Teoh, S. H. (2012). Overvalued equity and financing decisions. The Review of Financial Studies, 25(12), 3645-3683.

Driver, C., Temple, P., \& Urga, G. (2005). Profitability, capacity, and uncertainty: A model of UK manufacturing investment. Oxford Economic Papers, 57(1), 120-141.

Drnevich, P. L., \& Kriauciunas, A. P. (2011). Clarifying the conditions and limits of the contributions of ordinary and dynamic capabilities to relative firm performance. Strategic management journal, 32(3), 254279.

Duchin, R., Ozbas, O., \& Sensoy, B. A. (2010). Costly external finance, corporate investment, and the subprime mortgage credit crisis.Journal of Financial Economics, 97(3), 418-435.

Dudley, E. (2012). Capital structure and large investment projects. Journal of Corporate Finance, 18(5), 11681192.

Ebrahim, M. S., Girma, S., Shah, M. E., \& Williams, J. (2014). Dynamic capital structure and political patronage: The case of malaysia. International Review of Financial Analysis, 31, 117-128.

Fama, E. F., \& French, K. R. (2002). Testing trade-off and pecking order predictions about dividends and debt. The Review of Financial Studies, 15(1), 1-33.

Fazzari, S., Hubbard, R. G., \& Petersen, B. (1988). Investment, financing decisions, and tax policy. The American Economic Review, 78(2), 200-205.

Fazzari, S. M., Hubbard, R. G., \& Petersen, B. C. (1988). Financing constraints and corporate investment. Brookings Papers on Economic Activity, 1988(1), 141-195.

Ferris, S. P., Jayaraman, N., \& Sabherwal, S. (2013). CEO overconfidence and international merger and acquisition activity. Journal of Financial and Quantitative Analysis, 48(1), 137-164.

Fiegenbaum, A., Hart, S., \& Schendel, D. (1996). Strategic reference point theory. Strategic Management Journal, 17(3), 219-235.

Firth, M., Lin, C., \& Wong, S. M. (2008). Leverage and investment under a state-owned bank lending environment: Evidence from China. Journal of Corporate Finance, 14(5), 642-653.

Fosu, S., Danso, A., Ahmad, W., \& Coffie, W. (2016). Information asymmetry, leverage and firm value: Do crisis and growth matter? International Review of Financial Analysis, 46, 140-150.

Frank, M. Z., \& Goyal, V. K. (2007). Corporate leverage: How much do managers really matter? Working paper, University of Minnesota.

Froot, K. A., Scharfstein, D. S., \& Stein, J. C. (1993). Risk management: Coordinating corporate investment and financing policies. The Journal of Finance, 48(5), 1629-1658.

Galasso, A., \& Simcoe, T. S. (2011). CEO overconfidence and innovation. Management Science, 57(8), 14691484. 
Gatchev, V. A., Pulvino, T., \& Tarhan, V. (2010). The interdependent and intertemporal nature of financial decisions: An application to cash flow sensitivities. The Journal of Finance, 65(2), 725-763.

Gennaioli, N., Ma, Y., \& Shleifer, A. (2016). Expectations and investment. NBER Macroeconomics Annual, 30(1), 379-431.

Goel, A. M., \& Thakor, A. V. (2008). Overconfidence, CEO selection, and corporate governance. The Journal of Finance, 63(6), 2737-2784.

Graham, J. R., Harvey, C. R., \& Puri, M. (2013). Managerial attitudes and corporate actions. Journal of Financial Economics, 109(1), 103-121.

Greve, H. R. (2003). A behavioral theory of R\&D expenditures and innovations: Evidence from shipbuilding. Academy of Management Journal, 46(6), 685-702.

Griffin, D., \& Tversky, A. (1992). The weighing of evidence and the determinants of confidence. Cognitive Psychology, 24(3), 411-435.

Grout, P. A., \& Zalewska, A. (2016). Stock market risk in the financial crisis. International Review of Financial Analysis, 46, 326-345.

Guney, Y., Li, L., \& Fairchild, R. (2011). The relationship between product market competition and capital structure in Chinese listed firms. International Review of Financial Analysis, 20(1), 41-51.

Hackbarth, D. (2008). Managerial traits and capital structure decisions. Journal of Financial and Quantitative Analysis, 43(4), 843-881.

Hackbarth, D. (2009). Determinants of corporate borrowing: A behavioral perspective. Journal of Corporate Finance, 15(4), 389-411.

Heaton, J. B. (2002). Managerial optimism and corporate finance. Financial Management, 33-45.

Hermalin, B. E., \& Katz, M. L. (2000). Corporate diversification and agency. Incentives, Organization, and Public Economics: Papers in Honour of Sir James Mirrlees, 17-39.

Hirshleifer, D. (2015). Behavioral finance. Annual Review of Financial Economics, 7, 133-159.

Hirshleifer, D., Low, A., \& Teoh, S. H. (2012). Are overconfident CEOs better innovators? The Journal of Finance, 67(4), 1457-1498.

Ho, P., Huang, C., Lin, C., \& Yen, J. (2016). CEO overconfidence and financial crisis: Evidence from bank lending and leverage. Journal of Financial Economics, 120(1), 194-209.

Hribar, P., Melessa, S. J., Small, R. C., \& Wilde, J. H. (2017). Does managerial sentiment affect accrual estimates? evidence from the banking industry. Journal of Accounting and Economics, 63(1), 26-50.

Huang, R., Tan, K. J. K., \& Faff, R. W. (2016). CEO overconfidence and corporate debt maturity. Journal of Corporate Finance, 36, 93-110.

Iwasaki, I. (2014). Global financial crisis, corporate governance, and firm survival: The Russian experience. Journal of Comparative Economics, 42(1), 178-211.

Ivashina, V., \& Scharfstein, D. (2010). Bank lending during the financial crisis of 2008. Journal of Financial Economics, 97(3), 319-338.

Jensen, M. C. (1986). Agency costs of free cash flow, corporate finance, and takeovers. The American Economic Review, 76(2), 323-329.

Jensen, M. C., \& Meckling, W. H. (1976). Theory of the firm: Managerial behavior, agency costs and ownership structure. Journal of Financial Economics, 3(4), 305-360. 
Jiang, F., Lee, J., Martin, X., \& Zhou, G. (2018). Manager sentiment and stock returns. Journal of Financial Economics,

Kahle, K. M., \& Stulz, R. M. (2013). Access to capital, investment, and the financial crisis. Journal of Financial Economics, 110(2), 280-299.

Kahneman, D. (1979). Prospect theory: An analysis of decisions under risk. Econometrica, 47, 278.

Katsikeas, C. S., Samiee, S., \& Theodosiou, M. (2006). Strategy fit and performance consequences of international marketing standardization. Strategic Management Journal, 27(9), 867-890.

Kim, H., Kim, H., \& Lee, P. M. (2008). Ownership structure and the relationship between financial slack and R\&D investments: Evidence from Korean firms. Organization Science, 19(3), 404-418.

Kim, J., Wang, Z., \& Zhang, L. (2016). CEO overconfidence and stock price crash risk. Contemporary Accounting Research, 33(4), 1720-1749.

Kotlar, J., Fang, H., De Massis, A., \& Frattini, F. (2014). Profitability goals, control goals, and the R \& D investment decisions of family and nonfamily firms. Journal of Product Innovation Management, 31(6), 1128-1145.

Lambert, J., \& Mulkay, B. (1987). Investment in a Disequilibrium Context Or Does Profitability Really Matter? Université catholique de Louvain, Center for Operations Research and Econometrics (CORE). (No. 1987003).

Landier, A., \& Thesmar, D. (2008). Financial contracting with optimistic entrepreneurs. The Review of Financial Studies, 22(1), 117-150.

Larwood, L., \& Whittaker, W. (1977). Managerial myopia: Self-serving biases in organizational planning. Journal of Applied Psychology, 62(2), 194.

Lee, C., Wang, C., Chiu, W., \& Tien, T. (2018). Managerial ability and corporate investment opportunity. International Review of Financial Analysis, 57, 65-76.

Lemmon, M., \& Portniaguina, E. (2006). Consumer confidence and asset prices: Some empirical evidence. The Review of Financial Studies, 19(4), 1499-1529.

Ljungqvist, A., Nanda, V., \& Singh, R. (2006). Hot markets, investor sentiment, and IPO pricing. The Journal of Business, 79(4), 1667-1702.

Malinvaud, E., \& Malinvaud, H. E. (1980). Profitability and unemployment. Cambridge University Press, Cambridge.

Malmendier, U., \& Tate, G. (2005). CEO overconfidence and corporate investment. The Journal of Finance, 60(6), 2661-2700.

Malmendier, U., \& Tate, G. (2008). Who makes acquisitions? CEO overconfidence and the market's reaction. Journal of Financial Economics, 89(1), 20-43.

Malmendier, U., Tate, G., \& Yan, J. (2011). Overconfidence and early-life experiences: The effect of managerial traits on corporate financial policies. The Journal of Finance, 66(5), 1687-1733.

March, J. G., \& Shapira, Z. (1987). Managerial perspectives on risk and risk taking. Management Science, 33(11), 1404-1418.

Masulis, R. W., \& Mobbs, S. (2011). Are all inside directors the same? evidence from the external directorship market. The Journal of Finance, 66(3), 823-872.

Medoff, J. L., Sellers, R. W., \& Cheongsiatomy, J. (2004). Labor's capital, business confidence, and the market for loanable funds. Harvard Institute of Economic Research Discussion Paper No. 2042 
Myers, S. C. (1984). The capital structure puzzle. The Journal of Finance, 39(3), 574-592.

Myers, S. C., \& Majluf, N. S. (1984). Corporate financing and investment decisions when firms have information that investors do not have. Journal of Financial Economics, 13(2), 187-221.

Ngah-Kiing Lim, E., Das, S. S., \& Das, A. (2009). Diversification strategy, capital structure, and the Asian financial crisis (1997-1998): Evidence from Singapore firms. Strategic Management Journal, 30(6), $577-$ 594.

O'Brien, J. P. (2003). The capital structure implications of pursuing a strategy of innovation. Strategic Management Journal, 24(5), 415-431.

O'Brien, J. P., David, P., Yoshikawa, T., \& Delios, A. (2014). How capital structure influences diversification performance: A transaction cost perspective. Strategic Management Journal, 35(7), 1013-1031.

Panousi, V., \& Papanikolaou, D. (2012). Investment, idiosyncratic risk, and ownership. The Journal of Finance, 67(3), 1113-1148.

Parsons, C., \& Titman, S. (2009). Capital structure and corporate strategy. Handbook of empirical corporate finance, 203-234 ed. BE Eckbo, Vol. 2, Chapter 13. Amsterdam: Elsevier/North-Holland.

Paunov, C. (2012). The global crisis and firms' investments in innovation. Research Policy, 41(1), 24-35.

Pegels, C. C., Song, Y. I., \& Yang, B. (2000). Management heterogeneity, competitive interaction groups, and firm performance. Strategic Management Journal, 21(9), 911-923.

Pikulina, E., Renneboog, L., \& Tobler, P. N. (2017). Overconfidence and investment: An experimental approach. Journal of Corporate Finance, 43, 175-192.

Precious, M. (1985). Demand constraints, rational expectations and investment theory. Oxford Economic Papers, 37(4), 576-605.

Paunov, C. (2012). The global crisis and firms' investments in innovation. Research Policy, 41(1), 24-35.

Richardson, S. (2006). Over-investment of free cash flow. Review of Accounting Studies, 11(2-3), 159-189.

Richardson, S. A. (2003) Corporate Governance and the Over-Investment of Surplus Cash., Doctoral dissertation.

Shapiro, A. H., Sudhof, M., \& Wilson, D. (2018). Measuring news sentiment. Paper presented at the

Shapiro, S. P. (2005). Agency theory. Annual Review of Sociology, 31

Shefrin, H. (2008). A behavioral approach to asset pricing Elsevier.

Simon, H. A. (1955). A behavioral model of rational choice. The Quarterly Journal of Economics, 69(1), 99118.

Song, F., \& Thakor, A. V. (2006). Information control, career concerns, and corporate governance. The Journal of Finance, 61(4), 1845-1896.

Souleles, N. S. (2004). Expectations, heterogeneous forecast errors, and consumption: Micro evidence from the michigan consumer sentiment surveys. Journal of Money, Credit and Banking, 39-72.

Stulz, R. (1990). Managerial discretion and optimal financing policies. Journal of Financial Economics, 26(1), 3-27.

Svenson, O. (1981). Are we all less risky and more skillful than our fellow drivers? Acta Psychologica, 47(2), 143-148. 
Titman, S., \& Wessels, R. (1988). The determinants of capital structure choice. The Journal of Finance, 43(1), 1-19.

Tucker, J., \& Stoja, E. (2011). Industry membership and capital structure dynamics in the UK. International Review of Financial Analysis, 20(4), 207-214.

Vendrame, V., Tucker, J., \& Guermat, C. (2016). Some extensions of the CAPM for individual assets. International Review of Financial Analysis, 44, 78-85.

Vogt, S. C. (1994). The cash flow/investment relationship: Evidence from US manufacturing firms. Financial Management, 3-20.

Weinstein, N. D. (1980). Unrealistic optimism about future life events. Journal of Personality and Social Psychology, 39(5), 806.

Wooldridge, J. M. (2009). Introductory econometrics: A modern approach, 4th international student edition. Cincinnati: South-Western Cengage Learning: South-Western Cengage Learning, 212

Yim, S. (2013). The acquisitiveness of youth: CEO age and acquisition behavior. Journal of Financial Economics, 108(1), 250-273.

Zou, H., \& Xiao, J. Z. (2006). The financing behaviour of listed Chinese firms. The British Accounting Review, 38(3), 239-258. 
Table 1: Description of variables

\begin{tabular}{ll}
\hline Variables & Description \\
\hline $\begin{array}{l}\text { Panel I: Dependent variables } \\
\text { Investment (1) } \\
(I N V 1)\end{array}$ & $\begin{array}{l}\text { Investment } 1 \text { is the ratio of net capital expenditure (capital expenditure minus } \\
\text { depreciation) of firm } i \text { to the book value of total property, plant and equipment } \\
\text { for the current year (Aivazian, 2005; Dang 2011). }\end{array}$ \\
$\begin{array}{l}\text { Investment (2) } \\
(I N V 2)\end{array}$ & $\begin{array}{l}\text { Investment } 2 \text { is the ratio of total capital expenditure of firm i to the book value } \\
\text { of total property, plant and equipment for the current year (Chava and Roberts, } \\
\text { 2008). }\end{array}$ \\
\hline $\begin{array}{l}\text { Investment (3) } \\
(I N V 3)\end{array}$ & $\begin{array}{l}\text { Investment } 3 \text { is the ratio of net capital expenditure (capital expenditure minus } \\
\text { depreciation) of firm i to book value of total assets for the current year (Firth } \\
\text { et al. 2008). }\end{array}$ \\
\hline
\end{tabular}

\section{Panel II: Independent variables}

Market Sentiments

(MSent)

Market sentiment measured as the average of the past 4 quarter Conference Board Measure of CEOs' Confidence.

Alternate measure of sentiment based on a composite of ten seasonally adjusted

Small Business Optimism components from survey of its members. Given that nearly $50 \%$ of the US Index (SBOpt) private workforce work for small businesses, the measure proxies for the health of small businesses.

University of Michigan
consumer sentiment index
$($ UMSent $)$

Chicago Board Options Exchange Volatility Index (VIX)

Alternate measure of sentiment estimated based on telephone surveys on a nationally representative sample of households. The measure proxies for the future course of the national economy.

Alternate measure of sentiment computed from exchange-traded option prices on the S\&P 500 Index. Specifically, the VIX is computed from the prices of out-of-the-money put and call options on the S\&P 500 Index. The CBOE VIX is the most widely followed benchmark of expected short-term market volatility for market participants.

\section{Panel II: Control variables}

Firm size (SZ) Firm size is the natural logarithm of the book value of Total Assets.

Asset tangibility Asset tangibility is the ratio of fixed assets to the book value of total $(T A N)$ assets.

Non-Debt Tax Shield Non-Debt Tax Shield is the ratio of depreciation expense to the book (NDTS) value of total assets.

Return on assets $(R O A)$

Return on assets is the ratio of total operating profit plus depreciation and profitability and the availability of internal funds.

Firm growth $(G R) \quad$ The one-year growth rate of sales.

Earnings volatility is the standard deviation in annual operating income over

Earnings Volatility

$(E V O L)$

Dividend (DIV)

Systematic Risk (SYSRISK) last 10 years to average (absolute) operating income over last 10 years. The measure is computed only for firms that have been in existence (and have data) for the last 10 years.

Dividend is a proxy for whether a firm pays common dividends (i.e. a variable equal to one if a firm pays common dividends, and zero otherwise). It also proxies for financial constraints.

Systematic risk captures how an asset covaries with the economy rather than with individual assets/company. The CAPM specifies that the expected excess return on any stock $i$ is proportional to systematic risk (beta). Thus, we decompose the total weekly return of a firm into a market and/or industry 


\begin{tabular}{ll}
\hline & (systematic), and a firm-specific or idiosyncratic component: $r_{i, t}-r f_{t}=\alpha_{i}+$ \\
& $\beta_{i}\left(m k t r f_{t}-r f_{t}\right)+\varepsilon_{i, t}$ \\
& where $r_{i, t}=$ stock $i$ return during period $t, m k t r f_{t}=$ Fama-French excess \\
market return during period $t$ and $r f_{t}$ is the risk-free rate during period $t$. \\
Systematic risk is captured from the beta $\left(\beta_{i}\right)$ of the standard CAPM market \\
model. \\
Idiosyncratic (unsystematic) risk captures risk caused by internal factors \\
associated with independent assets/company rather than the economy. We \\
measure the annual idiosyncratic investment volatility for firm $i$ as the volatility \\
of the residuals across the 52 weekly observations. Hence, idiosyncratic risk is \\
the volatility or standard deviation of the regression residuals (error term, $\left.\varepsilon_{i, t}\right)$, \\
i.e. $\sigma_{i e}=\sqrt{\sum_{\tau \in t} \varepsilon_{i, \tau}^{2}}$ \\
(IDIORISK)
\end{tabular}

The table presents the mnemonics and description of each dependent and independent variable used in this paper.

Table 2: Descriptive statistics

\begin{tabular}{lcccccccc}
\hline & Mean & $\begin{array}{c}\text { St. } \\
\text { Dev. }\end{array}$ & Min & Max & 25th \% & 50th \% & 75th \% & Observations \\
\hline MSent & 0.54 & 0.08 & 0.35 & 0.67 & 0.50 & 0.53 & 0.61 & 76166 \\
SBOpt & 0.95 & 0.05 & 0.87 & 1.05 & 0.90 & 0.96 & 1.01 & 76166 \\
UMSent & -0.00 & 0.91 & -1.41 & 1.44 & -1.09 & 0.36 & 0.75 & 76166 \\
VIX & 0.20 & 0.07 & 0.11 & 0.33 & 0.14 & 0.18 & 0.24 & 76166 \\
INV & -0.07 & 0.34 & -1.00 & 0.56 & -0.15 & -0.01 & 0.07 & 76166 \\
INV2 & 0.28 & 0.28 & 0.00 & 1.03 & 0.09 & 0.19 & 0.38 & 76166 \\
INV3 & 0.00 & 0.05 & -0.09 & 0.12 & -0.02 & 0.00 & 0.01 & 76166 \\
SZ & 5.34 & 2.52 & 0.47 & 9.75 & 3.54 & 5.45 & 7.20 & 76166 \\
TAN & 0.23 & 0.23 & 0.00 & 0.77 & 0.04 & 0.14 & 0.35 & 56388 \\
NDTS & 0.04 & 0.03 & 0.00 & 0.13 & 0.02 & 0.03 & 0.06 & 56388 \\
ROA & 0.04 & 0.23 & -0.65 & 0.32 & 0.00 & 0.10 & 0.17 & 53230 \\
GR & 0.07 & 0.68 & -0.90 & 1.96 & -0.35 & -0.04 & 0.29 & 76166 \\
EVOL & 0.52 & 0.38 & 0.00 & 1.45 & 0.27 & 0.44 & 0.71 & 50004 \\
DIV & 0.27 & 0.45 & 0.00 & 1.00 & 0.00 & 0.00 & 1.00 & 60098 \\
SYSRISK & 1.06 & 1.16 & -9.90 & 9.86 & 0.36 & 0.93 & 1.57 & 61380 \\
IDIORISK & 0.45 & 0.40 & 0.00 & 9.56 & 0.19 & 0.34 & 0.58 & 50139 \\
\hline Observations & 76166 & & & & & & &
\end{tabular}

Observations 76166

This table presents the descriptive statistics for the data. The sample comprises 14,089 US firms over the period 2003 to 2014. The variable descriptions are provided in Table 1 above. 
Table 3: Correlations matrix

\begin{tabular}{|c|c|c|c|c|c|c|c|c|c|c|c|c|c|c|c|c|}
\hline & MSent & UMSent & SBOpt & VIX & INV & INV2 & INV3 & SZZ & TANN & NDTSS & ROAA & GRR & EVOLL & DIVV & Beta & STVOL \\
\hline MSent & 1.00 & & & & & & & & & & & & & & & \\
\hline UMSent & $0.56^{*}$ & 1.00 & & & & & & & & & & & & & & \\
\hline SBOpt & $0.49^{*}$ & $0.94^{*}$ & 1.00 & & & & & & & & & & & & & \\
\hline VIX & $0.48^{*}$ & $0.82^{*}$ & $0.69^{*}$ & 1.00 & & & & & & & & & & & & \\
\hline INV & -0.01 & $-0.05^{*}$ & $-0.06^{*}$ & $-0.05^{*}$ & 1.00 & & & & & & & & & & & \\
\hline INV2 & 0.01 & $-0.07^{*}$ & $-0.07^{*}$ & $-0.09^{*}$ & $0.31^{*}$ & 1.00 & & & & & & & & & & \\
\hline INV3 & -0.00 & $-0.08^{*}$ & $-0.08^{*}$ & $-0.08^{*}$ & $0.72^{*}$ & $0.40^{*}$ & 1.00 & & & & & & & & & \\
\hline SZ & $0.03^{*}$ & -0.01 & $-0.02^{*}$ & $0.02^{*}$ & $0.19^{*}$ & $-0.12^{*}$ & $0.18^{*}$ & 1.00 & & & & & & & & \\
\hline TAN & $0.02^{*}$ & $0.04^{*}$ & $0.05^{*}$ & $0.04^{*}$ & $0.28^{*}$ & $-0.26^{*}$ & $0.30^{*}$ & $0.17^{*}$ & 1.00 & & & & & & & \\
\hline NDTS & $0.02^{*}$ & $0.11^{*}$ & $0.12^{*}$ & $0.08^{*}$ & $-0.25^{*}$ & $-0.07^{*}$ & $-0.26^{*}$ & $-0.13^{*}$ & $0.37^{*}$ & 1.00 & & & & & & \\
\hline ROA & $0.02^{*}$ & $0.06^{*}$ & $0.06^{*}$ & $0.04^{*}$ & $0.21^{*}$ & 0.01 & $0.21^{*}$ & $0.50^{*}$ & $0.22^{*}$ & -0.00 & 1.00 & & & & & \\
\hline GR & $-0.06^{*}$ & $0.13^{*}$ & $0.04^{*}$ & $0.12^{*}$ & $-0.02^{*}$ & $-0.02^{*}$ & $-0.03^{*}$ & $-0.05^{*}$ & $0.02^{*}$ & $0.06^{*}$ & $-0.07^{*}$ & 1.00 & & & & \\
\hline EVOL & $0.21^{*}$ & $0.08^{*}$ & $0.07^{*}$ & $0.13^{*}$ & $-0.17^{*}$ & $0.05^{*}$ & $-0.17^{*}$ & $-0.34^{*}$ & $-0.09^{*}$ & $0.16^{*}$ & $-0.28^{*}$ & $0.05^{*}$ & 1.00 & & & \\
\hline DIV & $0.02^{*}$ & -0.01 & -0.01 & -0.01 & $0.13^{*}$ & $-0.17^{*}$ & $0.11^{*}$ & $0.50^{*}$ & $0.13^{*}$ & $-0.12^{*}$ & $0.28^{*}$ & $-0.02^{*}$ & $-0.34^{*}$ & 1.00 & & \\
\hline SYSRISK & $-0.04^{*}$ & $-0.15^{*}$ & $-0.13^{*}$ & $-0.13^{*}$ & $-0.06^{*}$ & $0.07^{*}$ & $-0.04^{*}$ & $0.09^{*}$ & $-0.05^{*}$ & $0.06^{*}$ & $-0.03^{*}$ & 0.01 & $0.31^{*}$ & $-0.10^{*}$ & 1.00 & \\
\hline IDIORISK & $0.08^{*}$ & $-0.06^{*}$ & -0.01 & $-0.02^{*}$ & $-0.09^{*}$ & $0.05^{*}$ & $-0.08^{*}$ & $-0.26^{*}$ & $-0.05^{*}$ & $0.09^{*}$ & $-0.24^{*}$ & $-0.03^{*}$ & $0.26^{*}$ & $-0.22^{*}$ & $0.15^{*}$ & 1.00 \\
\hline
\end{tabular}


Table 4: Entire period regression - The Sentiment-Investment nexus

\begin{tabular}{|c|c|c|c|c|c|c|c|c|c|c|c|c|}
\hline & \multicolumn{4}{|c|}{ Investment 1} & \multicolumn{4}{|c|}{ Investment 2} & \multicolumn{4}{|c|}{ Investment 3} \\
\hline & (1) & $(2)$ & (3) & (4) & $(5)$ & (6) & $(7)$ & (8) & (9) & (10) & (11) & (12) \\
\hline MSent & $\begin{array}{c}0.788^{* * *} \\
(0.120)\end{array}$ & $\begin{array}{c}0.616^{* * * *} \\
(0.131)\end{array}$ & $\begin{array}{c}0.833^{* * *} \\
(0.119)\end{array}$ & $\begin{array}{c}0.656^{* * *} \\
(0.133)\end{array}$ & $\begin{array}{c}0.547^{* * *} \\
(0.117)\end{array}$ & $\begin{array}{c}0.485^{* * *} \\
(0.120)\end{array}$ & $\begin{array}{l}0.594^{* * *} \\
(0.116)\end{array}$ & $\begin{array}{c}0.599^{* * *} \\
(0.121)\end{array}$ & $\begin{array}{l}0.135^{* * *} \\
(0.014)\end{array}$ & $\begin{array}{l}0.118^{* * * *} \\
(0.017)\end{array}$ & $\begin{array}{c}0.141^{* * * *} \\
(0.014)\end{array}$ & $\begin{array}{l}0.128^{* * * *} \\
(0.017)\end{array}$ \\
\hline $\mathrm{SZ}$ & & $\begin{array}{c}-0.045^{* * *} \\
(0.006)\end{array}$ & & $\begin{array}{c}-0.005^{\text {**** }} \\
(0.002)\end{array}$ & & $\begin{array}{c}-0.065^{\text {*** }} \\
(0.005)\end{array}$ & & $\begin{array}{c}-0.017^{* * *} \\
(0.001)\end{array}$ & & $\begin{array}{c}-0.007^{\text {*** }} \\
(0.001)\end{array}$ & & $\begin{array}{c}-0.001^{\text {*** }} \\
(0.000)\end{array}$ \\
\hline TAN & & $\begin{array}{c}0.031 \\
(0.037)\end{array}$ & & $\begin{array}{c}0.457^{* * *} \\
(0.016)\end{array}$ & & $\begin{array}{c}-0.737^{\text {*** }} \\
(0.032)\end{array}$ & & $\begin{array}{c}-0.409^{* * *} \\
(0.012)\end{array}$ & & $\begin{array}{c}-0.034^{* * *} \\
(0.005)\end{array}$ & & $\begin{array}{l}0.052^{* * * *} \\
(0.002)\end{array}$ \\
\hline NDTS & & $\begin{array}{c}-3.142^{* * *} \\
(0.153)\end{array}$ & & $\begin{array}{c}-3.350^{* * *} \\
(0.106)\end{array}$ & & $\begin{array}{c}-1.758^{* * *} \\
(0.125)\end{array}$ & & $\begin{array}{c}-0.843^{* * *} \\
(0.086)\end{array}$ & & $\begin{array}{c}-0.439^{* * *} \\
(0.017)\end{array}$ & & $\begin{array}{c}-0.485^{\text {*** }} \\
(0.013)\end{array}$ \\
\hline ROA & & $\begin{array}{c}0.205^{* * *} \\
(0.022)\end{array}$ & & $\begin{array}{c}0.212^{* * *} \\
(0.016)\end{array}$ & & $\begin{array}{c}0.271^{* * *} \\
(0.020)\end{array}$ & & $\begin{array}{c}0.235^{* * *} \\
(0.014)\end{array}$ & & $\begin{array}{c}0.030^{* * *} \\
(0.002)\end{array}$ & & $\begin{array}{c}0.029^{* * * *} \\
(0.002)\end{array}$ \\
\hline GR & & $\begin{array}{c}0.001 \\
(0.003)\end{array}$ & & $\begin{array}{c}0.004 \\
(0.002)\end{array}$ & & $\begin{array}{c}0.003 \\
(0.002)\end{array}$ & & $\begin{array}{c}0.006^{* * *} \\
(0.002)\end{array}$ & & $\begin{array}{c}0.000 \\
(0.000)\end{array}$ & & $\begin{array}{c}0.001^{* * *} \\
(0.000)\end{array}$ \\
\hline EVOL & & $\begin{array}{c}-0.007 \\
(0.010)\end{array}$ & & $\begin{array}{l}-0.003 \\
(0.008)\end{array}$ & & $\begin{array}{c}-0.028^{* * *} \\
(0.008)\end{array}$ & & $\begin{array}{c}-0.014^{* *} \\
(0.007)\end{array}$ & & $\begin{array}{c}-0.003^{* *} \\
(0.001)\end{array}$ & & $\begin{array}{c}-0.002^{* *} \\
(0.001)\end{array}$ \\
\hline DIV & & $\begin{array}{c}0.013^{*} \\
(0.007)\end{array}$ & & $\begin{array}{l}0.012^{* *} \\
(0.005)\end{array}$ & & $\begin{array}{l}-0.002 \\
(0.005)\end{array}$ & & $\begin{array}{c}-0.024^{* * *} \\
(0.004)\end{array}$ & & $\begin{array}{l}0.003^{* * *} \\
(0.001)\end{array}$ & & $\begin{array}{c}0.002^{* * *} \\
(0.001)\end{array}$ \\
\hline SYSRISK & & $\begin{array}{c}0.004 \\
(0.003)\end{array}$ & & $\begin{array}{c}0.003 \\
(0.002)\end{array}$ & & $\begin{array}{c}0.002 \\
(0.002)\end{array}$ & & $\begin{array}{c}0.003 \\
(0.002)\end{array}$ & & $\begin{array}{c}0.000 \\
(0.000)\end{array}$ & & $\begin{array}{c}0.000 \\
(0.000)\end{array}$ \\
\hline IDIORISK & & $\begin{array}{c}-0.011 \\
(0.011)\end{array}$ & & $\begin{array}{c}-0.024^{* * *} \\
(0.008)\end{array}$ & & $\begin{array}{c}0.006 \\
(0.009)\end{array}$ & & $\begin{array}{c}0.008 \\
(0.007)\end{array}$ & & $\begin{array}{c}-0.003^{* *} \\
(0.001)\end{array}$ & & $\begin{array}{c}-0.004^{\text {**** }} \\
(0.001)\end{array}$ \\
\hline _cons & $\begin{array}{c}-0.569^{* * *} \\
(0.071)\end{array}$ & $\begin{array}{c}-0.064 \\
(0.086)\end{array}$ & $\begin{array}{c}-0.606^{* * *} \\
(0.071)\end{array}$ & $\begin{array}{c}-0.433^{* * *} \\
(0.080)\end{array}$ & $\begin{array}{c}-0.075 \\
(0.069)\end{array}$ & $\begin{array}{c}0.622^{* * *} \\
(0.078)\end{array}$ & $\begin{array}{c}-0.090 \\
(0.069)\end{array}$ & $\begin{array}{l}0.150^{* *} \\
(0.073)\end{array}$ & $\begin{array}{c}-0.084^{* * *} \\
(0.008)\end{array}$ & $\begin{array}{c}-0.003 \\
(0.011)\end{array}$ & $\begin{array}{c}-0.087^{* * *} \\
(0.008)\end{array}$ & $\begin{array}{c}-0.063^{\text {*** }} \\
(0.010)\end{array}$ \\
\hline Fixed Effect & Yes & Yes & No & No & Yes & Yes & No & No & Yes & Yes & No & No \\
\hline$N$ & 52196 & 34475 & 52196 & 34475 & 52196 & 34475 & 52196 & 34475 & 70235 & 35104 & 70235 & 35104 \\
\hline $\mathrm{r} 2$ & 0.017 & 0.082 & 0.018 & 0.092 & 0.033 & 0.152 & 0.053 & 0.172 & 0.032 & 0.129 & 0.052 & 0.159 \\
\hline N_clust & 9817 & 6547 & 9817 & 6547 & 9817 & 6547 & 9817 & 6547 & 13218 & 6657 & 13218 & 6657 \\
\hline
\end{tabular}

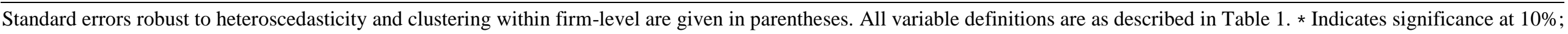
** Indicates significance at 5\%; *** Indicates significance at $1 \%$. 
Table 5: Alternative measure of sentiment - Small Business Optimism (SBOpt)

\begin{tabular}{|c|c|c|c|c|c|c|c|c|c|c|c|c|}
\hline \multirow{2}{*}{ 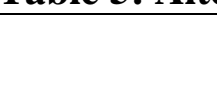 } & \multicolumn{4}{|c|}{ Investment 1} & \multicolumn{4}{|c|}{ Investment 2} & \multicolumn{4}{|c|}{ Investment 3} \\
\hline & (1) & (2) & (3) & (4) & (5) & (6) & (7) & (8) & (9) & (10) & (11) & $(12)$ \\
\hline SBOpt & $\begin{array}{c}0.869^{* * * *} \\
(0.132)\end{array}$ & $\begin{array}{l}0.679^{* * *} \\
(0.145)\end{array}$ & $\begin{array}{l}0.919^{* * * *} \\
(0.132)\end{array}$ & $\begin{array}{l}0.690^{* * * *} \\
(0.146)\end{array}$ & $\begin{array}{l}0.603^{* * * *} \\
(0.129)\end{array}$ & $\begin{array}{l}0.535^{* * * *} \\
(0.132)\end{array}$ & $\begin{array}{l}0.655^{* * * *} \\
(0.128)\end{array}$ & $\begin{array}{c}0.659^{* * * *} \\
(0.133)\end{array}$ & $\begin{array}{l}0.149^{* * * *} \\
(0.015)\end{array}$ & $\begin{array}{l}0.130^{* * * *} \\
(0.018)\end{array}$ & $\begin{array}{c}0.155^{* * * *} \\
(0.015)\end{array}$ & $\begin{array}{l}0.134^{* * * *} \\
(0.019)\end{array}$ \\
\hline SZ & & $\begin{array}{c}-0.045^{* * *} \\
(0.006)\end{array}$ & & $\begin{array}{c}-0.005^{* * *} \\
(0.002)\end{array}$ & & $\begin{array}{c}-0.065^{\text {**** }} \\
(0.005)\end{array}$ & & $\begin{array}{c}-0.017^{* * * *} \\
(0.001)\end{array}$ & & $\begin{array}{c}-0.007^{* * * *} \\
(0.001)\end{array}$ & & $\begin{array}{c}-0.001^{* * *} \\
(0.000)\end{array}$ \\
\hline TAN & & $\begin{array}{c}0.031 \\
(0.037)\end{array}$ & & $\begin{array}{c}0.457^{* * *} \\
(0.016)\end{array}$ & & $\begin{array}{c}-0.737^{\text {**** }} \\
(0.032)\end{array}$ & & $\begin{array}{c}-0.409^{* * *} \\
(0.012)\end{array}$ & & $\begin{array}{c}-0.034^{* * *} \\
(0.005)\end{array}$ & & $\begin{array}{c}0.052^{* * * *} \\
(0.002)\end{array}$ \\
\hline NDTS & & $\begin{array}{c}-3.142^{* * *} \\
(0.153)\end{array}$ & & $\begin{array}{c}-3.350^{* * * *} \\
(0.106)\end{array}$ & & $\begin{array}{c}-1.758^{* * * *} \\
(0.125)\end{array}$ & & $\begin{array}{c}-0.843^{* * * *} \\
(0.086)\end{array}$ & & $\begin{array}{c}-0.439^{* * * *} \\
(0.017)\end{array}$ & & $\begin{array}{c}-0.485^{* * *} \\
(0.013)\end{array}$ \\
\hline ROA & & $\begin{array}{c}0.205^{* * *} \\
(0.022)\end{array}$ & & $\begin{array}{l}0.212^{* * *} \\
(0.016)\end{array}$ & & $\begin{array}{c}0.271^{* * * *} \\
(0.020)\end{array}$ & & $\begin{array}{c}0.235^{* * * *} \\
(0.014)\end{array}$ & & $\begin{array}{c}0.030^{* * * *} \\
(0.002)\end{array}$ & & $\begin{array}{c}0.029^{* * * *} \\
(0.002)\end{array}$ \\
\hline GR & & $\begin{array}{c}0.001 \\
(0.003)\end{array}$ & & $\begin{array}{c}0.004 \\
(0.002)\end{array}$ & & $\begin{array}{c}0.003 \\
(0.002)\end{array}$ & & $\begin{array}{c}0.006^{* * * *} \\
(0.002)\end{array}$ & & $\begin{array}{c}0.000 \\
(0.000)\end{array}$ & & $\begin{array}{c}0.001^{* * * *} \\
(0.000)\end{array}$ \\
\hline EVOL & & $\begin{array}{l}-0.007 \\
(0.010)\end{array}$ & & $\begin{array}{l}-0.003 \\
(0.008)\end{array}$ & & $\begin{array}{c}-0.028^{* * * *} \\
(0.008)\end{array}$ & & $\begin{array}{c}-0.014^{* *} \\
(0.007)\end{array}$ & & $\begin{array}{l}-0.003^{* * *} \\
(0.001)\end{array}$ & & $\begin{array}{c}-0.002^{* *} \\
(0.001)\end{array}$ \\
\hline DIV & & $\begin{array}{l}0.013^{*} \\
(0.007)\end{array}$ & & $\begin{array}{l}0.012^{* *} \\
(0.005)\end{array}$ & & $\begin{array}{l}-0.002 \\
(0.005)\end{array}$ & & $\begin{array}{c}-0.024^{* * * *} \\
(0.004)\end{array}$ & & $\begin{array}{c}0.003^{* * * *} \\
(0.001)\end{array}$ & & $\begin{array}{c}0.002^{* * * *} \\
(0.001)\end{array}$ \\
\hline SYSRISK & & $\begin{array}{c}0.004 \\
(0.003)\end{array}$ & & $\begin{array}{c}0.003 \\
(0.002)\end{array}$ & & $\begin{array}{c}0.002 \\
(0.002)\end{array}$ & & $\begin{array}{c}0.003 \\
(0.002)\end{array}$ & & $\begin{array}{c}0.000 \\
(0.000)\end{array}$ & & $\begin{array}{c}0.000 \\
(0.000)\end{array}$ \\
\hline IDIORISK & & $\begin{array}{l}-0.011 \\
(0.011)\end{array}$ & & $\begin{array}{c}-0.024^{* * * *} \\
(0.008)\end{array}$ & & $\begin{array}{c}0.006 \\
(0.009)\end{array}$ & & $\begin{array}{c}0.008 \\
(0.007)\end{array}$ & & $\begin{array}{l}-0.003^{* * *} \\
(0.001)\end{array}$ & & $\begin{array}{c}-0.004^{* * *} \\
(0.001)\end{array}$ \\
\hline _cons & $\begin{array}{c}-0.919^{* * *} \\
(0.124)\end{array}$ & $\begin{array}{c}-0.338^{* *} \\
(0.140)\end{array}$ & $\begin{array}{c}-0.976^{* * * *} \\
(0.124)\end{array}$ & $\begin{array}{c}-0.033^{* *} \\
(0.014)\end{array}$ & $\begin{array}{c}-0.318^{* * *} \\
(0.121)\end{array}$ & $\begin{array}{c}0.407^{* * * *} \\
(0.128)\end{array}$ & $\begin{array}{c}-0.354^{* * *} \\
(0.120)\end{array}$ & $\begin{array}{c}0.515^{* * *} \\
(0.011)\end{array}$ & $\begin{array}{c}-0.144^{* * *} \\
(0.014)\end{array}$ & $\begin{array}{c}-0.055^{* * *} \\
(0.018)\end{array}$ & $\begin{array}{c}-0.149^{* * * *} \\
(0.014)\end{array}$ & $\begin{array}{c}0.015^{* * * *} \\
(0.001)\end{array}$ \\
\hline Fixed Effect & Yes & Yes & No & No & Yes & Yes & No & No & Yes & Yes & No & No \\
\hline$N$ & 52196 & 34475 & 52196 & 34475 & 52196 & 34475 & 52196 & 34475 & 70235 & 35104 & 70235 & 35104 \\
\hline $\mathrm{r} 2$ & 0.017 & 0.082 & 0.018 & 0.092 & 0.033 & 0.152 & 0.053 & 0.172 & 0.032 & 0.129 & 0.052 & 0.159 \\
\hline N_clust & 9817 & 6547 & 9817 & 6547 & 9817 & 6547 & 9817 & 6547 & 13218 & 6657 & 13218 & 6657 \\
\hline
\end{tabular}

Standard errors robust to heteroscedasticity and clustering within firm-level are given in parentheses. All variable definitions are as described in Table 1. * Indicates significance at $10 \%$; $* *$ Indicates significance at $5 \% ; * * *$ Indicates significance at $1 \%$. 
Table 6: Alternative measure of sentiment - Michigan Sentiment Index (UMSent)

\begin{tabular}{|c|c|c|c|c|c|c|c|c|c|c|c|c|}
\hline & \multicolumn{4}{|c|}{ Investment 1} & \multicolumn{4}{|c|}{ Investment 2} & \multicolumn{4}{|c|}{ Investment 3} \\
\hline & (1) & (2) & $(3)$ & (4) & (5) & (6) & (7) & $(8)$ & (9) & (10) & (11) & $(12)$ \\
\hline UMSent & $\begin{array}{l}0.075^{* * *} \\
(0.011)\end{array}$ & $\begin{array}{l}0.059^{* * * *} \\
(0.013)\end{array}$ & $\begin{array}{l}0.079^{* * * *} \\
(0.011)\end{array}$ & $\begin{array}{l}0.062^{* * * *} \\
(0.013)\end{array}$ & $\begin{array}{c}0.052^{\text {*** }} \\
(0.011)\end{array}$ & $\begin{array}{l}0.049^{* * * *} \\
(0.011)\end{array}$ & $\begin{array}{c}0.057^{* * * *} \\
(0.011)\end{array}$ & $\begin{array}{l}0.059^{* * * *} \\
(0.012)\end{array}$ & $\begin{array}{l}0.029^{\text {**** }} \\
(0.002)\end{array}$ & $\begin{array}{l}0.011^{* * * *} \\
(0.002)\end{array}$ & $\begin{array}{c}0.022^{* * * *} \\
(0.002)\end{array}$ & $\begin{array}{l}0.012^{\text {**** }} \\
(0.002)\end{array}$ \\
\hline SZ & & $\begin{array}{c}-0.045^{* * *} \\
(0.006)\end{array}$ & & $\begin{array}{c}-0.005^{* * *} \\
(0.002)\end{array}$ & & $\begin{array}{c}-0.065^{* * *} \\
(0.005)\end{array}$ & & $\begin{array}{c}-0.017^{* * *} \\
(0.001)\end{array}$ & & $\begin{array}{c}-0.007^{* * *} \\
(0.001)\end{array}$ & & $\begin{array}{c}-0.001^{* * * *} \\
(0.000)\end{array}$ \\
\hline TAN & & $\begin{array}{c}0.027 \\
(0.037)\end{array}$ & & $\begin{array}{c}0.457^{\text {**** }} \\
(0.016)\end{array}$ & & $\begin{array}{c}-0.739^{* * *} \\
(0.032)\end{array}$ & & $\begin{array}{c}-0.410^{* * *} \\
(0.012)\end{array}$ & & $\begin{array}{c}-0.034^{* * *} \\
(0.006)\end{array}$ & & $\begin{array}{c}0.052^{\text {***** }} \\
(0.002)\end{array}$ \\
\hline NDTS & & $\begin{array}{c}-3.148^{* * *} \\
(0.154)\end{array}$ & & $\begin{array}{c}-3.366^{* * *} \\
(0.106)\end{array}$ & & $\begin{array}{c}-1.761^{* * *} \\
(0.125)\end{array}$ & & $\begin{array}{c}-0.841^{* * *} \\
(0.086)\end{array}$ & & $\begin{array}{c}-0.440^{* * * *} \\
(0.017)\end{array}$ & & $\begin{array}{c}-0.487^{* * * *} \\
(0.013)\end{array}$ \\
\hline ROA & & $\begin{array}{l}0.208^{* * * *} \\
(0.022)\end{array}$ & & $\begin{array}{c}0.216^{* * * *} \\
(0.016)\end{array}$ & & $\begin{array}{c}0.275^{* * * *} \\
(0.020)\end{array}$ & & $\begin{array}{c}0.236^{* * * *} \\
(0.014)\end{array}$ & & $\begin{array}{c}0.030^{* * * *} \\
(0.002)\end{array}$ & & $\begin{array}{c}0.030^{\text {**** }} \\
(0.002)\end{array}$ \\
\hline GR & & $\begin{array}{c}0.001 \\
(0.003)\end{array}$ & & $\begin{array}{l}0.004^{*} \\
(0.002)\end{array}$ & & $\begin{array}{c}0.003 \\
(0.002)\end{array}$ & & $\begin{array}{c}0.006^{* * *} \\
(0.002)\end{array}$ & & $\begin{array}{c}0.000 \\
(0.000)\end{array}$ & & $\begin{array}{c}0.001^{* * * *} \\
(0.000)\end{array}$ \\
\hline EVOL & & $\begin{array}{l}-0.008 \\
(0.010)\end{array}$ & & $\begin{array}{l}-0.006 \\
(0.008)\end{array}$ & & $\begin{array}{c}-0.025^{* * *} \\
(0.008)\end{array}$ & & $\begin{array}{l}-0.012^{*} \\
(0.007)\end{array}$ & & $\begin{array}{c}-0.003^{* * *} \\
(0.001)\end{array}$ & & $\begin{array}{c}-0.003^{* * *} \\
(0.001)\end{array}$ \\
\hline DIV & & $\begin{array}{l}0.013^{*} \\
(0.007)\end{array}$ & & $\begin{array}{c}0.013^{\text {**** }} \\
(0.005)\end{array}$ & & $\begin{array}{l}-0.002 \\
(0.005)\end{array}$ & & $\begin{array}{c}-0.024^{* * *} \\
(0.004)\end{array}$ & & $\begin{array}{c}0.003^{* * * *} \\
(0.001)\end{array}$ & & $\begin{array}{l}0.002^{\text {**** }} \\
(0.001)\end{array}$ \\
\hline SYSRISK & & $\begin{array}{c}0.004 \\
(0.002)\end{array}$ & & $\begin{array}{c}0.002 \\
(0.002)\end{array}$ & & $\begin{array}{c}0.001 \\
(0.002)\end{array}$ & & $\begin{array}{c}0.003 \\
(0.002)\end{array}$ & & $\begin{array}{c}0.000 \\
(0.000)\end{array}$ & & $\begin{array}{l}-0.000 \\
(0.000)\end{array}$ \\
\hline IDIORISK & & $\begin{array}{l}-0.007 \\
(0.007)\end{array}$ & & $\begin{array}{l}-0.009 \\
(0.006)\end{array}$ & & $\begin{array}{c}0.003 \\
(0.005)\end{array}$ & & $\begin{array}{c}0.004 \\
(0.005)\end{array}$ & & $\begin{array}{l}-0.002^{* *} \\
(0.001)\end{array}$ & & $\begin{array}{c}-0.002^{* * *} \\
(0.001)\end{array}$ \\
\hline _cons & $\begin{array}{c}-0.115^{* * *} \\
(0.004)\end{array}$ & $\begin{array}{c}0.290^{* * * *} \\
(0.041)\end{array}$ & $\begin{array}{c}-0.126^{* * *} \\
(0.005)\end{array}$ & $\begin{array}{c}-0.061^{* * *} \\
(0.014)\end{array}$ & $\begin{array}{c}0.240^{\text {**** }} \\
(0.003)\end{array}$ & $\begin{array}{l}0.904^{* * *} \\
(0.033)\end{array}$ & $\begin{array}{c}0.253^{* * * *} \\
(0.004)\end{array}$ & $\begin{array}{c}0.497^{* * *} \\
(0.011)\end{array}$ & $\begin{array}{c}-0.011^{* * *} \\
(0.001)\end{array}$ & $\begin{array}{c}0.065^{* * *} \\
(0.005)\end{array}$ & $\begin{array}{c}-0.009^{* * * *} \\
(0.001)\end{array}$ & $\begin{array}{l}0.010^{* * *} \\
(0.001)\end{array}$ \\
\hline Fixed Effect & Yes & Yes & No & No & Yes & Yes & No & No & Yes & Yes & No & No \\
\hline$N$ & 52196 & 34397 & 52196 & 34397 & 52196 & 34397 & 52196 & 34397 & 70235 & 35024 & 70235 & 35024 \\
\hline r2 & 0.017 & 0.082 & 0.018 & 0.092 & 0.033 & 0.153 & 0.053 & 0.173 & 0.032 & 0.129 & 0.052 & 0.159 \\
\hline N_clust & 9817 & 6540 & 9817 & 6540 & 9817 & 6540 & 9817 & 6540 & 13218 & 6650 & 13218 & 6650 \\
\hline
\end{tabular}

Standard errors robust to heteroscedasticity and clustering within firm-level are given in parentheses. All variable definitions are as described in Table 1. * Indicates significance at 10\%; $* *$ Indicates significance at $5 \% ; * * *$ Indicates significance at $1 \%$. 
Table 7: Alternative measure of sentiment - CBOE VIX

\begin{tabular}{|c|c|c|c|c|c|c|c|c|c|c|c|c|}
\hline & \multicolumn{4}{|c|}{ Investment 1} & \multicolumn{4}{|c|}{ Investment 2} & \multicolumn{4}{|c|}{ Investment 3} \\
\hline & (1) & $(2)$ & $(3)$ & (4) & (5) & (6) & $(7)$ & $(8)$ & (9) & $(10)$ & (11) & (12) \\
\hline VIX & $\begin{array}{l}0.510^{* * * *} \\
(0.078)\end{array}$ & $\begin{array}{c}0.398^{* * * *} \\
(0.085)\end{array}$ & $\begin{array}{c}0.539^{* * *} \\
(0.077)\end{array}$ & $\begin{array}{c}0.420^{* * * *} \\
(0.086)\end{array}$ & $\begin{array}{c}0.354^{* * * *} \\
(0.075)\end{array}$ & $\begin{array}{c}0.331^{* * *} \\
(0.078)\end{array}$ & $\begin{array}{l}0.384^{* * * *} \\
(0.075)\end{array}$ & $\begin{array}{c}0.401^{* * * *} \\
(0.079)\end{array}$ & $\begin{array}{l}0.014^{* * *} \\
(0.011)\end{array}$ & $\begin{array}{c}0.078^{* * * *} \\
(0.011)\end{array}$ & $\begin{array}{l}0.011^{\text {*** }} \\
(0.010)\end{array}$ & $\begin{array}{c}0.084^{\text {**** }} \\
(0.011)\end{array}$ \\
\hline SZ & & $\begin{array}{c}-0.045^{* * *} \\
(0.006)\end{array}$ & & $\begin{array}{c}-0.005^{* * *} \\
(0.002)\end{array}$ & & $\begin{array}{c}-0.065^{* * *} \\
(0.005)\end{array}$ & & $\begin{array}{c}-0.017^{\text {*** }} \\
(0.001)\end{array}$ & & $\begin{array}{c}-0.007^{\text {*** }} \\
(0.001)\end{array}$ & & $\begin{array}{c}-0.001^{* * *} \\
(0.000)\end{array}$ \\
\hline TAN & & $\begin{array}{c}0.027 \\
(0.037)\end{array}$ & & $\begin{array}{c}0.457^{* * * *} \\
(0.016)\end{array}$ & & $\begin{array}{c}-0.739^{* * *} \\
(0.032)\end{array}$ & & $\begin{array}{c}-0.410^{\text {*** }} \\
(0.012)\end{array}$ & & $\begin{array}{c}-0.034^{\text {**** }} \\
(0.006)\end{array}$ & & $\begin{array}{c}0.052^{* * *} \\
(0.002)\end{array}$ \\
\hline NDTS & & $\begin{array}{c}-3.148^{* * *} \\
(0.154)\end{array}$ & & $\begin{array}{c}-3.366^{\text {*** }} \\
(0.106)\end{array}$ & & $\begin{array}{c}-1.761^{* * *} \\
(0.125)\end{array}$ & & $\begin{array}{c}-0.841^{\text {**** }} \\
(0.086)\end{array}$ & & $\begin{array}{c}-0.440^{\text {**** }} \\
(0.017)\end{array}$ & & $\begin{array}{c}-0.487^{* * *} \\
(0.013)\end{array}$ \\
\hline ROA & & $\begin{array}{l}0.208^{* * *} \\
(0.022)\end{array}$ & & $\begin{array}{l}0.216^{* * *} \\
(0.016)\end{array}$ & & $\begin{array}{l}0.275^{* * *} \\
(0.020)\end{array}$ & & $\begin{array}{l}0.236^{* * * *} \\
(0.014)\end{array}$ & & $\begin{array}{c}0.030^{* * *} \\
(0.002)\end{array}$ & & $\begin{array}{c}0.030^{* * * *} \\
(0.002)\end{array}$ \\
\hline GR & & $\begin{array}{c}0.001 \\
(0.003)\end{array}$ & & $\begin{array}{c}0.004^{*} \\
(0.002)\end{array}$ & & $\begin{array}{c}0.003 \\
(0.002)\end{array}$ & & $\begin{array}{l}0.006^{* * *} \\
(0.002)\end{array}$ & & $\begin{array}{c}0.000 \\
(0.000)\end{array}$ & & $\begin{array}{c}0.001^{* * *} \\
(0.000)\end{array}$ \\
\hline EVOL & & $\begin{array}{l}-0.008 \\
(0.010)\end{array}$ & & $\begin{array}{c}-0.006 \\
(0.008)\end{array}$ & & $\begin{array}{c}-0.025^{* * *} \\
(0.008)\end{array}$ & & $\begin{array}{l}-0.012^{*} \\
(0.007)\end{array}$ & & $\begin{array}{c}-0.003^{* * *} \\
(0.001)\end{array}$ & & $\begin{array}{c}-0.003^{* * *} \\
(0.001)\end{array}$ \\
\hline DIV & & $\begin{array}{c}0.013^{*} \\
(0.007)\end{array}$ & & $\begin{array}{c}0.013^{* * *} \\
(0.005)\end{array}$ & & $\begin{array}{c}-0.002 \\
(0.005)\end{array}$ & & $\begin{array}{c}-0.024^{\text {**** }} \\
(0.004)\end{array}$ & & $\begin{array}{c}0.003^{* * *} \\
(0.001)\end{array}$ & & $\begin{array}{c}0.002^{* * *} \\
(0.001)\end{array}$ \\
\hline SYSRISK & & $\begin{array}{c}0.004 \\
(0.002)\end{array}$ & & $\begin{array}{c}0.002 \\
(0.002)\end{array}$ & & $\begin{array}{c}0.001 \\
(0.002)\end{array}$ & & $\begin{array}{c}0.003 \\
(0.002)\end{array}$ & & $\begin{array}{c}0.000 \\
(0.000)\end{array}$ & & $\begin{array}{c}-0.000 \\
(0.000)\end{array}$ \\
\hline IDIORISK & & $\begin{array}{l}-0.007 \\
(0.007)\end{array}$ & & $\begin{array}{l}-0.009 \\
(0.006)\end{array}$ & & $\begin{array}{c}0.003 \\
(0.005)\end{array}$ & & $\begin{array}{c}0.004 \\
(0.005)\end{array}$ & & $\begin{array}{c}-0.002^{* *} \\
(0.001)\end{array}$ & & $\begin{array}{c}-0.002^{* * *} \\
(0.001)\end{array}$ \\
\hline _cons & $\begin{array}{c}-4.383^{* * *} \\
(6.656)\end{array}$ & $\begin{array}{c}-3.387^{\text {*** }} \\
(7.291)\end{array}$ & $\begin{array}{c}-4.633^{* * *} \\
(6.620)\end{array}$ & $\begin{array}{c}-3.609^{* * *} \\
(7.375)\end{array}$ & $\begin{array}{c}-3.009^{* * *} \\
(6.475)\end{array}$ & $\begin{array}{c}-2.747^{* * *} \\
(6.678)\end{array}$ & $\begin{array}{c}-3.269^{* * *} \\
(6.440)\end{array}$ & $\begin{array}{c}-3.390^{* * *} \\
(6.751)\end{array}$ & $\begin{array}{l}0.123^{* * *} \\
(0.009)\end{array}$ & $\begin{array}{c}-6.595^{\text {**** }} \\
(0.925)\end{array}$ & $\begin{array}{c}0.092^{\text {*** }} \\
(0.009)\end{array}$ & $\begin{array}{c}-7.204^{* * *} \\
(0.952)\end{array}$ \\
\hline Fixed Effect & Yes & Yes & No & No & Yes & Yes & No & No & Yes & Yes & No & No \\
\hline$N$ & 52196 & 34397 & 52196 & 34397 & 52196 & 34397 & 52196 & 34397 & 70235 & 35024 & 70235 & 35024 \\
\hline $\mathrm{r} 2$ & 0.017 & 0.082 & 0.018 & 0.092 & 0.033 & 0.153 & 0.053 & 0.183 & 0.032 & 0.129 & 0.052 & 0.159 \\
\hline N_clust & 9817 & 6540 & 9817 & 6540 & 9817 & 6540 & 9817 & 6540 & 13218 & 6650 & 13218 & 6650 \\
\hline
\end{tabular}

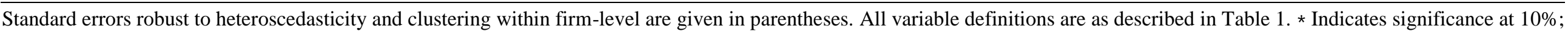
** Indicates significance at 5\%; *** Indicates significance at $1 \%$. 
Table 8: Sentiment on investment: 2-STEP GMM

\begin{tabular}{|c|c|c|c|}
\hline & Investment 1 & Investment 2 & Investment 3 \\
\hline MSent & $\begin{array}{c}3.253^{* * *} \\
(1.047)\end{array}$ & $\begin{array}{c}2.484^{* * *} \\
(0.995)\end{array}$ & $\begin{array}{c}0.600^{* * * *} \\
(0.133)\end{array}$ \\
\hline SZ & $\begin{array}{c}-0.022^{* * *} \\
(0.006)\end{array}$ & $\begin{array}{c}-0.037^{* * *} \\
(0.006)\end{array}$ & $\begin{array}{c}-0.005^{* * *} \\
(0.001)\end{array}$ \\
\hline TAN & $\begin{array}{c}0.505^{* * *} \\
(0.022)\end{array}$ & $\begin{array}{c}-0.292^{* * *} \\
(0.016)\end{array}$ & $\begin{array}{c}0.100^{* * *} \\
(0.003)\end{array}$ \\
\hline ROA & $\begin{array}{c}0.555^{* * *} \\
(0.051)\end{array}$ & $\begin{array}{c}0.363^{* * * *} \\
(0.044)\end{array}$ & $\begin{array}{c}0.079^{* * *} \\
(0.006)\end{array}$ \\
\hline GR & $\begin{array}{c}0.019^{*} \\
(0.010)\end{array}$ & $\begin{array}{c}0.008 \\
(0.009)\end{array}$ & $\begin{array}{c}0.002^{*} \\
(0.001)\end{array}$ \\
\hline EVOL & $\begin{array}{c}-0.199^{* * *} \\
(0.066)\end{array}$ & $\begin{array}{c}-0.175^{* * *} \\
(0.062)\end{array}$ & $\begin{array}{c}-0.045^{* * *} \\
(0.009)\end{array}$ \\
\hline DIV & $\begin{array}{c}-0.024^{* * *} \\
(0.009)\end{array}$ & $\begin{array}{c}-0.071^{* * *} \\
(0.007)\end{array}$ & $\begin{array}{c}-0.008^{* * *} \\
(0.001)\end{array}$ \\
\hline NDTS & $\begin{array}{c}-2.783^{* * *} \\
(0.212)\end{array}$ & $\begin{array}{c}0.312^{*} \\
(0.171)\end{array}$ & $\begin{array}{c}-0.398^{* * * *} \\
(0.030)\end{array}$ \\
\hline SYSRISK & $\begin{array}{c}0.053^{* * *} \\
(0.016)\end{array}$ & $\begin{array}{l}0.039^{* *} \\
(0.016)\end{array}$ & $\begin{array}{c}0.010^{* * * *} \\
(0.002)\end{array}$ \\
\hline IDIORISK & $\begin{array}{l}-0.056^{*} \\
(0.032)\end{array}$ & $\begin{array}{c}0.002 \\
(0.030)\end{array}$ & $\begin{array}{c}-0.010^{* * *} \\
(0.004)\end{array}$ \\
\hline _cons & $\begin{array}{c}-1.606^{* * *} \\
(0.494) \\
\end{array}$ & $\begin{array}{l}-0.668 \\
(0.469) \\
\end{array}$ & $\begin{array}{c}-0.276^{* * *} \\
(0.063) \\
\end{array}$ \\
\hline$N$ & 16594 & 16594 & 16682 \\
\hline Number of clusters & 3445 & 3445 & 3461 \\
\hline K-P WF statistic & 4.070 & 4.070 & 4.214 \\
\hline K-P LM statistic & 19.344 & 19.344 & 18.539 \\
\hline Hansen J statistic & 1.970 & 2.943 & 1.970 \\
\hline Hansen J p-value & 0.160 & 0.086 & 0.160 \\
\hline
\end{tabular}


Table 9: Effects of financial flexibility

\begin{tabular}{|c|c|c|c|c|c|c|c|c|}
\hline & \multicolumn{8}{|c|}{ Investment 1} \\
\hline & \multicolumn{4}{|c|}{ Panel A } & \multicolumn{4}{|c|}{ Panel B } \\
\hline & LC & $\mathrm{HC}$ & LL & $\mathrm{HL}$ & LCHL & LCLL & HCLL & HCHL \\
\hline MSent & $\begin{array}{c}0.470^{* * *} \\
(0.160)\end{array}$ & $\begin{array}{c}0.789^{* * *} \\
(0.215)\end{array}$ & $\begin{array}{l}1.024^{* * *} \\
(0.221)\end{array}$ & $\begin{array}{l}0.406^{* *} \\
(0.158)\end{array}$ & $\begin{array}{l}0.895^{\text {** }} \\
(0.351)\end{array}$ & $\begin{array}{l}0.359^{* *} \\
(0.174)\end{array}$ & $\begin{array}{l}1.060^{* * *} \\
(0.301)\end{array}$ & $\begin{array}{l}0.694^{* *} \\
(0.298)\end{array}$ \\
\hline SZ & $\begin{array}{c}-0.058^{\text {**** }} \\
(0.008)\end{array}$ & $\begin{array}{c}-0.037^{* * *} \\
(0.009)\end{array}$ & $\begin{array}{c}-0.054^{\text {**** }} \\
(0.009)\end{array}$ & $\begin{array}{c}-0.034^{* * *} \\
(0.009)\end{array}$ & $\begin{array}{c}-0.057^{* * *} \\
(0.016)\end{array}$ & $\begin{array}{c}-0.052^{* * * *} \\
(0.011)\end{array}$ & $\begin{array}{c}-0.049^{* * *} \\
(0.012)\end{array}$ & $\begin{array}{l}-0.018 \\
(0.013)\end{array}$ \\
\hline TAN & $\begin{array}{c}0.016 \\
(0.051)\end{array}$ & $\begin{array}{l}-0.027 \\
(0.051)\end{array}$ & $\begin{array}{c}-0.075 \\
(0.061)\end{array}$ & $\begin{array}{c}-0.014 \\
(0.048)\end{array}$ & $\begin{array}{l}-0.134 \\
(0.099)\end{array}$ & $\begin{array}{c}0.018 \\
(0.067)\end{array}$ & $\begin{array}{l}-0.099 \\
(0.074)\end{array}$ & $\begin{array}{c}-0.088 \\
(0.076)\end{array}$ \\
\hline NDTS & $\begin{array}{c}-2.986^{\text {*** }} \\
(0.231)\end{array}$ & $\begin{array}{c}-3.128^{* * *} \\
(0.218)\end{array}$ & $\begin{array}{c}-3.498^{* * *} \\
(0.213)\end{array}$ & $\begin{array}{c}-2.335^{* * *} \\
(0.240)\end{array}$ & $\begin{array}{c}-3.054^{\text {**** }} \\
(0.376)\end{array}$ & $\begin{array}{c}-2.723^{\text {*** }} \\
(0.316)\end{array}$ & $\begin{array}{c}-3.482^{* * *} \\
(0.280)\end{array}$ & $\begin{array}{c}-2.045^{\text {*** }} \\
(0.374)\end{array}$ \\
\hline ROA & $\begin{array}{c}0.239^{* * *} \\
(0.036)\end{array}$ & $\begin{array}{l}0.181^{* * *} \\
(0.029)\end{array}$ & $\begin{array}{c}0.177^{\text {*** }} \\
(0.028)\end{array}$ & $\begin{array}{c}0.246^{* * *} \\
(0.036)\end{array}$ & $\begin{array}{c}0.226^{* * *} \\
(0.054)\end{array}$ & $\begin{array}{c}0.253^{* * *} \\
(0.054)\end{array}$ & $\begin{array}{c}0.155^{* * *} \\
(0.036)\end{array}$ & $\begin{array}{c}0.186^{* * * *} \\
(0.053)\end{array}$ \\
\hline GR & $\begin{array}{c}0.002 \\
(0.004)\end{array}$ & $\begin{array}{c}0.001 \\
(0.003)\end{array}$ & $\begin{array}{c}0.000 \\
(0.003)\end{array}$ & $\begin{array}{l}-0.001 \\
(0.004)\end{array}$ & $\begin{array}{c}0.001 \\
(0.007)\end{array}$ & $\begin{array}{l}-0.001 \\
(0.005)\end{array}$ & $\begin{array}{c}0.002 \\
(0.004)\end{array}$ & $\begin{array}{l}-0.005 \\
(0.007)\end{array}$ \\
\hline EVOL & $\begin{array}{l}-0.024^{*} \\
(0.014)\end{array}$ & $\begin{array}{c}0.010 \\
(0.015)\end{array}$ & $\begin{array}{c}-0.001 \\
(0.016)\end{array}$ & $\begin{array}{l}-0.008 \\
(0.012)\end{array}$ & $\begin{array}{c}0.014 \\
(0.030)\end{array}$ & $\begin{array}{c}-0.039^{* *} \\
(0.015)\end{array}$ & $\begin{array}{l}-0.007 \\
(0.021)\end{array}$ & $\begin{array}{c}0.029 \\
(0.021)\end{array}$ \\
\hline DIV & $\begin{array}{c}0.007 \\
(0.007)\end{array}$ & $\begin{array}{c}0.018 \\
(0.012)\end{array}$ & $\begin{array}{l}0.023^{* *} \\
(0.011)\end{array}$ & $\begin{array}{c}0.008 \\
(0.007)\end{array}$ & $\begin{array}{c}0.012 \\
(0.018)\end{array}$ & $\begin{array}{c}0.009 \\
(0.008)\end{array}$ & $\begin{array}{l}0.035^{* *} \\
(0.015)\end{array}$ & $\begin{array}{c}-0.014 \\
(0.017)\end{array}$ \\
\hline SYSRISK & $\begin{array}{c}0.003 \\
(0.003)\end{array}$ & $\begin{array}{c}0.002 \\
(0.004)\end{array}$ & $\begin{array}{c}0.006 \\
(0.004)\end{array}$ & $\begin{array}{c}0.002 \\
(0.003)\end{array}$ & $\begin{array}{c}0.001 \\
(0.007)\end{array}$ & $\begin{array}{l}0.006^{*} \\
(0.004)\end{array}$ & $\begin{array}{c}0.006 \\
(0.005)\end{array}$ & $\begin{array}{l}-0.002 \\
(0.005)\end{array}$ \\
\hline IDIORISK & $\begin{array}{l}-0.008 \\
(0.008)\end{array}$ & $\begin{array}{l}-0.006 \\
(0.011)\end{array}$ & $\begin{array}{c}0.006 \\
(0.010)\end{array}$ & $\begin{array}{l}-0.016^{*} \\
(0.009)\end{array}$ & $\begin{array}{l}-0.012 \\
(0.017)\end{array}$ & $\begin{array}{l}-0.010 \\
(0.009)\end{array}$ & $\begin{array}{c}0.016 \\
(0.013)\end{array}$ & $\begin{array}{c}-0.030^{* *} \\
(0.014)\end{array}$ \\
\hline _cons & $\begin{array}{c}0.174 \\
(0.108)\end{array}$ & $\begin{array}{c}-0.276^{* *} \\
(0.138)\end{array}$ & $\begin{array}{c}-0.285^{* *} \\
(0.141)\end{array}$ & $\begin{array}{c}0.010 \\
(0.109)\end{array}$ & $\begin{array}{c}-0.075 \\
(0.227)\end{array}$ & $\begin{array}{c}0.201 \\
(0.128)\end{array}$ & $\begin{array}{c}-0.396^{* *} \\
(0.192)\end{array}$ & $\begin{array}{l}-0.295 \\
(0.195)\end{array}$ \\
\hline Fixed Effect & Yes & Yes & Yes & Yes & Yes & Yes & Yes & Yes \\
\hline$N$ & 17467 & 16930 & 16662 & 17735 & 6623 & 10844 & 10039 & 6891 \\
\hline r2 & 0.085 & 0.080 & 0.095 & 0.066 & 0.085 & 0.090 & 0.094 & 0.057 \\
\hline N_clust & 4387 & 4664 & 3960 & 4502 & 2305 & 3060 & 2925 & 2755 \\
\hline
\end{tabular}

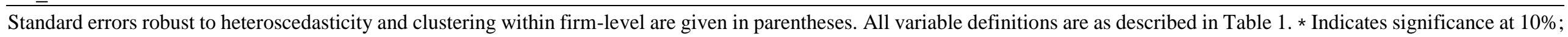
$* *$ Indicates significance at 5\%; *** Indicates significance at $1 \%$. 
Table 10: Does future profitability matter?

\begin{tabular}{|c|c|c|c|c|c|c|c|c|c|c|c|c|}
\hline & \multicolumn{4}{|c|}{ Investment 1} & \multicolumn{4}{|c|}{ Investment 2} & \multicolumn{4}{|c|}{ Investment 3} \\
\hline & (1) & (2) & (3) & (4) & $(5)$ & (6) & (7) & (8) & (9) & $(10)$ & (11) & (12) \\
\hline MSent & $\begin{array}{c}0.553^{* * *} \\
(0.075)\end{array}$ & $\begin{array}{l}0.375^{* * *} \\
(0.094)\end{array}$ & $\begin{array}{l}0.542^{* * *} \\
(0.078)\end{array}$ & $\begin{array}{c}0.369^{* * * *} \\
(0.096)\end{array}$ & $\begin{array}{c}0.797^{* * * *} \\
(0.080)\end{array}$ & $\begin{array}{c}0.480^{* * * *} \\
(0.087)\end{array}$ & $\begin{array}{l}0.802^{* * *} \\
(0.081)\end{array}$ & $\begin{array}{c}0.491^{* * *} \\
(0.088)\end{array}$ & $\begin{array}{l}0.089^{* * * *} \\
(0.012)\end{array}$ & $\begin{array}{l}0.044^{* * *} \\
(0.012)\end{array}$ & $\begin{array}{l}0.096^{* * *} \\
(0.013)\end{array}$ & $\begin{array}{l}0.044^{* * *} \\
(0.012)\end{array}$ \\
\hline Profma & $\begin{array}{c}0.001 \\
(0.001)\end{array}$ & $\begin{array}{l}0.002^{*} \\
(0.001)\end{array}$ & & & $\begin{array}{c}0.001 \\
(0.001)\end{array}$ & $\begin{array}{l}0.002^{* * *} \\
(0.001)\end{array}$ & & & $\begin{array}{c}0.001 \\
(0.001)\end{array}$ & $\begin{array}{l}0.000^{* *} \\
(0.000)\end{array}$ & & \\
\hline Profma $_{\mathrm{t}+1}$ & $\begin{array}{c}0.001 \\
(0.001)\end{array}$ & $\begin{array}{l}-0.001 \\
(0.001)\end{array}$ & & & $\begin{array}{c}0.001 \\
(0.001)\end{array}$ & $\begin{array}{c}-0.001 \\
(0.001)\end{array}$ & & & $\begin{array}{l}-0.000^{*} \\
(0.000)\end{array}$ & $\begin{array}{l}-0.001 \\
(0.001)\end{array}$ & & \\
\hline Profma $_{t+2}$ & $\begin{array}{l}-0.001 \\
(0.001)\end{array}$ & $\begin{array}{l}0.001^{*} \\
(0.001)\end{array}$ & & & $\begin{array}{l}-0.001 \\
(0.001)\end{array}$ & $\begin{array}{c}0.001 \\
(0.001)\end{array}$ & & & $\begin{array}{c}-0.001^{* * * *} \\
(0.001)\end{array}$ & $\begin{array}{c}0.001 \\
(0.001)\end{array}$ & & \\
\hline Profma $_{t+3}$ & $\begin{array}{c}0.001 \\
(0.001)\end{array}$ & $\begin{array}{l}-0.001 \\
(0.001)\end{array}$ & & & $\begin{array}{c}0.001 \\
(0.001)\end{array}$ & $\begin{array}{c}-0.001 \\
(0.001)\end{array}$ & & & $\begin{array}{c}-0.000^{* * * *} \\
(0.000)\end{array}$ & $\begin{array}{l}-0.001 \\
(0.001)\end{array}$ & & \\
\hline ROA & & & $\begin{array}{c}0.003 \\
(0.002)\end{array}$ & $\begin{array}{c}0.023^{* * *} \\
(0.009)\end{array}$ & & & $\begin{array}{l}0.008^{* *} \\
(0.004)\end{array}$ & $\begin{array}{l}0.030^{* *} \\
(0.012)\end{array}$ & & & $\begin{array}{c}0.000 \\
(0.000)\end{array}$ & $\begin{array}{c}0.001 \\
(0.001)\end{array}$ \\
\hline $\mathrm{ROA}_{t+1}$ & & & $\begin{array}{c}-0.006^{* * *} \\
(0.002)\end{array}$ & $\begin{array}{c}-0.026^{* * *} \\
(0.009)\end{array}$ & & & $\begin{array}{l}-0.005^{* *} \\
(0.002)\end{array}$ & $\begin{array}{c}-0.030^{* * *} \\
(0.013)\end{array}$ & & & $\begin{array}{l}-0.000 \\
(0.000)\end{array}$ & $\begin{array}{l}-0.000 \\
(0.001)\end{array}$ \\
\hline $\mathrm{ROA}_{\mathrm{t}+2}$ & & & $\begin{array}{l}-0.001 \\
(0.001)\end{array}$ & $\begin{array}{c}0.007 \\
(0.006)\end{array}$ & & & $\begin{array}{c}0.001 \\
(0.001)\end{array}$ & $\begin{array}{l}0.008^{*} \\
(0.004)\end{array}$ & & & $\begin{array}{c}0.000 \\
(0.000)\end{array}$ & $\begin{array}{l}-0.000 \\
(0.001)\end{array}$ \\
\hline $\mathrm{ROA}_{\mathrm{t}+3}$ & & & $\begin{array}{l}0.002^{* * * *} \\
(0.001)\end{array}$ & $\begin{array}{c}0.002^{*} \\
(0.001)\end{array}$ & & & $\begin{array}{l}0.002^{* *} \\
(0.001)\end{array}$ & $\begin{array}{l}0.003^{* * * *} \\
(0.001)\end{array}$ & & & $\begin{array}{c}0.000^{*} \\
(0.000)\end{array}$ & $\begin{array}{l}-0.001 \\
(0.001)\end{array}$ \\
\hline _cons & $\begin{array}{c}-0.353^{* * * *} \\
(0.043)\end{array}$ & $\begin{array}{c}0.139^{*} \\
(0.082)\end{array}$ & $\begin{array}{c}-0.351^{* * * *} \\
(0.044)\end{array}$ & $\begin{array}{c}0.160^{*} \\
(0.085)\end{array}$ & $\begin{array}{c}-0.154^{* * *} \\
(0.045)\end{array}$ & $\begin{array}{c}0.690^{* * * *} \\
(0.070)\end{array}$ & $\begin{array}{c}-0.149^{* * * *} \\
(0.046)\end{array}$ & $\begin{array}{c}0.699^{* * * *} \\
(0.072)\end{array}$ & $\begin{array}{c}-0.043^{* * * *} \\
(0.007)\end{array}$ & $\begin{array}{c}0.046^{* * *} \\
(0.010)\end{array}$ & $\begin{array}{c}-0.047^{* * * *} \\
(0.007)\end{array}$ & $\begin{array}{c}0.049^{* * * *} \\
(0.010)\end{array}$ \\
\hline Fixed Effect & Yes & Yes & Yes & Yes & Yes & Yes & Yes & Yes & Yes & Yes & Yes & Yes \\
\hline All Other Controls & No & Yes & No & Yes & No & Yes & No & Yes & No & Yes & No & Yes \\
\hline$N$ & 27739 & 18518 & 25621 & 18100 & 27739 & 18518 & 25621 & 18100 & 36846 & 18835 & 32786 & 18425 \\
\hline r2 & 0.008 & 0.060 & 0.009 & 0.062 & 0.023 & 0.134 & 0.026 & 0.139 & 0.026 & 0.098 & 0.029 & 0.099 \\
\hline N_clust & 5953 & 4128 & 5424 & 3993 & 5953 & 4128 & 5424 & 3993 & 7340 & 4192 & 6522 & 4059 \\
\hline
\end{tabular}

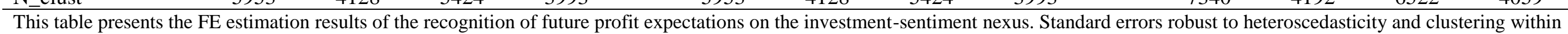

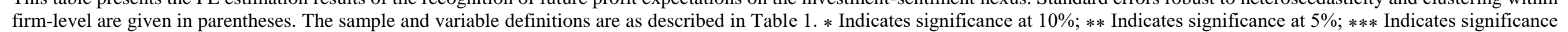
at $1 \%$. 
Table 11: Joint effect of flexibility-profitability

Investment 1

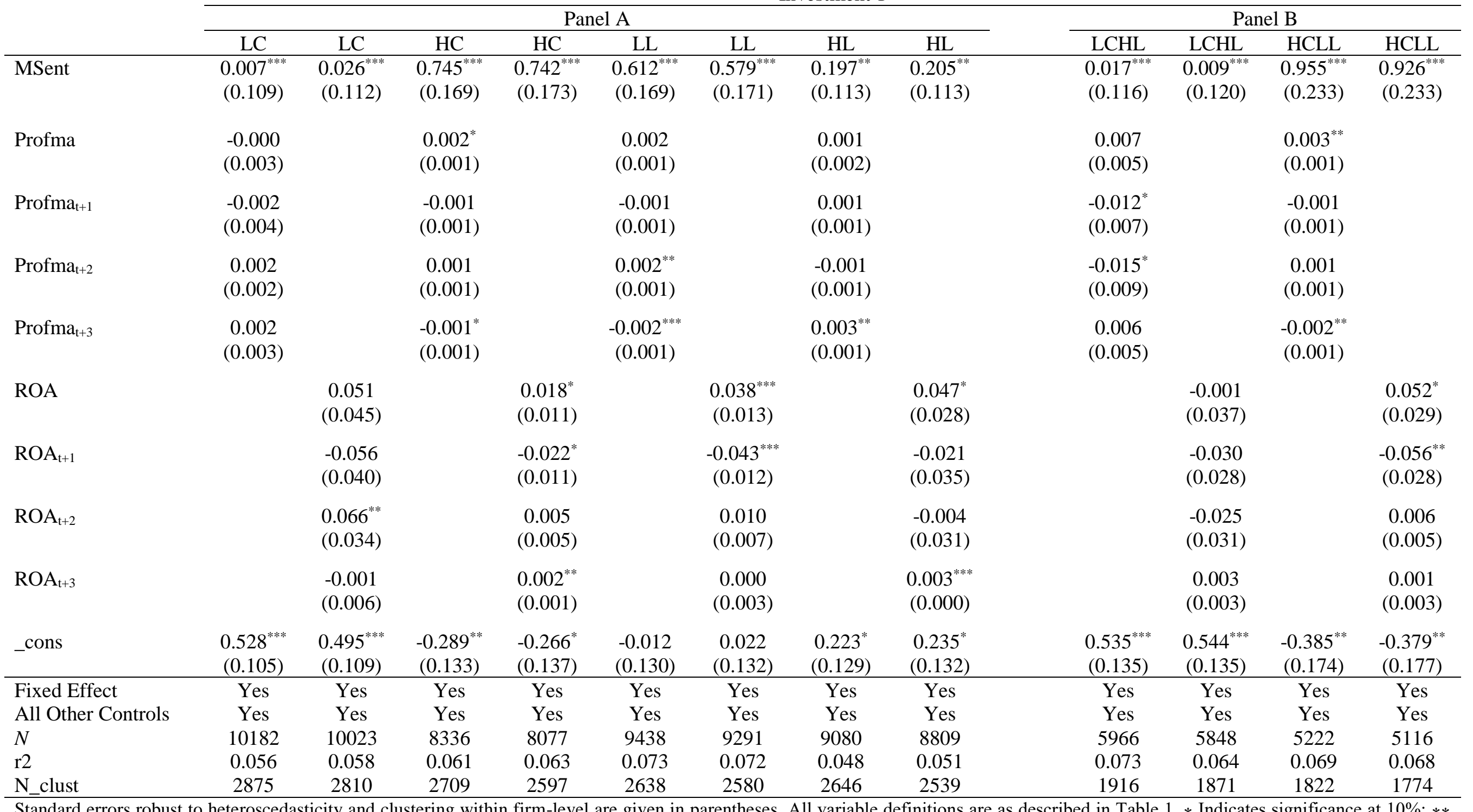

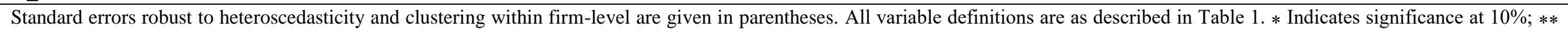
Indicates significance at 5\%; $* * *$ Indicates significance at $1 \%$. 
Table 12: Effects of crisis

\begin{tabular}{|c|c|c|c|c|c|c|c|c|c|}
\hline & \multicolumn{3}{|c|}{ Pre-Crisis } & \multicolumn{3}{|c|}{ Crisis } & \multicolumn{3}{|c|}{ Post-Crisis } \\
\hline & Investment 1 & Investment 2 & Investment 3 & Investment 1 & Investment 2 & Investment 3 & Investment 1 & Investment 2 & Investment 3 \\
\hline & $(1)$ & $(2)$ & $(3)$ & $(4)$ & $(5)$ & $(6)$ & $(7)$ & $(8)$ & (9) \\
\hline MSent & $\begin{array}{c}0.057 \\
(0.097)\end{array}$ & $\begin{array}{l}-0.116 \\
(0.086)\end{array}$ & $\begin{array}{c}0.007 \\
(0.014)\end{array}$ & $\begin{array}{l}0.063^{* *} \\
(0.027)\end{array}$ & $\begin{array}{l}0.060^{* *} \\
(0.025)\end{array}$ & $\begin{array}{c}0.013^{* * *} \\
(0.003)\end{array}$ & $\begin{array}{c}0.616^{* * *} \\
(0.134)\end{array}$ & $\begin{array}{c}0.527^{* * *} \\
(0.123)\end{array}$ & $\begin{array}{c}0.120^{* * *} \\
(0.017)\end{array}$ \\
\hline $\mathrm{SZ}$ & $\begin{array}{c}0.008 \\
(0.029)\end{array}$ & $\begin{array}{c}-0.136^{* * *} \\
(0.022)\end{array}$ & $\begin{array}{c}-0.015^{* * *} \\
(0.003)\end{array}$ & $\begin{array}{l}-0.040^{*} \\
(0.021)\end{array}$ & $\begin{array}{c}-0.130^{* * *} \\
(0.013)\end{array}$ & $\begin{array}{c}-0.010^{* * *} \\
(0.002)\end{array}$ & $\begin{array}{c}-0.066^{* * * *} \\
(0.009)\end{array}$ & $\begin{array}{c}-0.099^{* * *} \\
(0.007)\end{array}$ & $\begin{array}{c}-0.010^{* * *} \\
(0.001)\end{array}$ \\
\hline TAN & $\begin{array}{c}-0.705^{* * *} \\
(0.090)\end{array}$ & $\begin{array}{c}-1.363^{* * *} \\
(0.112)\end{array}$ & $\begin{array}{c}-0.172^{* * *} \\
(0.024)\end{array}$ & $\begin{array}{c}-0.393^{* * *} \\
(0.076)\end{array}$ & $\begin{array}{c}-1.201^{* * *} \\
(0.074)\end{array}$ & $\begin{array}{c}-0.098^{* * *} \\
(0.012)\end{array}$ & $\begin{array}{c}-0.111^{* * *} \\
(0.043)\end{array}$ & $\begin{array}{c}-0.864^{* * *} \\
(0.041)\end{array}$ & $\begin{array}{c}-0.050^{* * *} \\
(0.007)\end{array}$ \\
\hline NDTS & $\begin{array}{l}-0.216 \\
(0.271)\end{array}$ & $\begin{array}{c}-0.875^{\text {*** }} \\
(0.277)\end{array}$ & $\begin{array}{l}-0.049 \\
(0.038)\end{array}$ & $\begin{array}{c}-1.213^{* * *} \\
(0.368)\end{array}$ & $\begin{array}{c}-1.275^{\text {*** }} \\
(0.298)\end{array}$ & $\begin{array}{c}-0.164^{\text {**** }} \\
(0.037)\end{array}$ & $\begin{array}{c}-3.048^{* * *} \\
(0.228)\end{array}$ & $\begin{array}{c}-1.763^{* * *} \\
(0.183)\end{array}$ & $\begin{array}{c}-0.410^{* * * *} \\
(0.027)\end{array}$ \\
\hline ROA & $\begin{array}{c}0.049 \\
(0.054)\end{array}$ & $\begin{array}{c}0.209^{* * *} \\
(0.046)\end{array}$ & $\begin{array}{l}0.018^{* *} \\
(0.007)\end{array}$ & $\begin{array}{c}0.090^{*} \\
(0.048)\end{array}$ & $\begin{array}{c}0.186^{* * *} \\
(0.043)\end{array}$ & $\begin{array}{c}0.015^{* * *} \\
(0.005)\end{array}$ & $\begin{array}{c}0.219^{* * *} \\
(0.029)\end{array}$ & $\begin{array}{c}0.264^{* * *} \\
(0.025)\end{array}$ & $\begin{array}{c}0.028^{* * *} \\
(0.003)\end{array}$ \\
\hline GR & $\begin{array}{c}0.002 \\
(0.006)\end{array}$ & $\begin{array}{l}0.011^{* *} \\
(0.005)\end{array}$ & $\begin{array}{c}0.000 \\
(0.001)\end{array}$ & $\begin{array}{l}-0.009 \\
(0.006)\end{array}$ & $\begin{array}{l}-0.002 \\
(0.005)\end{array}$ & $\begin{array}{l}-0.000 \\
(0.001)\end{array}$ & $\begin{array}{c}0.000 \\
(0.003)\end{array}$ & $\begin{array}{c}0.001 \\
(0.003)\end{array}$ & $\begin{array}{c}0.000 \\
(0.000)\end{array}$ \\
\hline EVOL & $\begin{array}{c}0.007 \\
(0.028)\end{array}$ & $\begin{array}{c}0.029 \\
(0.026)\end{array}$ & $\begin{array}{l}-0.004 \\
(0.003)\end{array}$ & $\begin{array}{l}-0.009 \\
(0.018)\end{array}$ & $\begin{array}{c}-0.033^{* *} \\
(0.014)\end{array}$ & $\begin{array}{l}-0.001 \\
(0.002)\end{array}$ & $\begin{array}{l}-0.009 \\
(0.013)\end{array}$ & $\begin{array}{l}-0.019^{*} \\
(0.012)\end{array}$ & $\begin{array}{c}-0.005^{\text {**** }} \\
(0.002)\end{array}$ \\
\hline DIV & $\begin{array}{c}0.018 \\
(0.022)\end{array}$ & $\begin{array}{c}0.019 \\
(0.016)\end{array}$ & $\begin{array}{l}0.005^{* *} \\
(0.003)\end{array}$ & $\begin{array}{c}0.021 \\
(0.014)\end{array}$ & $\begin{array}{c}0.013 \\
(0.012)\end{array}$ & $\begin{array}{c}0.006^{* * *} \\
(0.002)\end{array}$ & $\begin{array}{c}0.007 \\
(0.008)\end{array}$ & $\begin{array}{l}-0.003 \\
(0.007)\end{array}$ & $\begin{array}{c}0.003^{* * *} \\
(0.001)\end{array}$ \\
\hline SYSRISK & $\begin{array}{c}0.002 \\
(0.010)\end{array}$ & $\begin{array}{c}0.006 \\
(0.008)\end{array}$ & $\begin{array}{l}-0.001 \\
(0.001)\end{array}$ & $\begin{array}{c}-0.000 \\
(0.004)\end{array}$ & $\begin{array}{c}0.002 \\
(0.003)\end{array}$ & $\begin{array}{c}0.000 \\
(0.000)\end{array}$ & $\begin{array}{l}0.006^{* *} \\
(0.003)\end{array}$ & $\begin{array}{l}0.006^{* *} \\
(0.003)\end{array}$ & $\begin{array}{c}0.000 \\
(0.000)\end{array}$ \\
\hline IDIORISK & $\begin{array}{c}0.023 \\
(0.016)\end{array}$ & $\begin{array}{c}0.055^{\text {*** }} \\
(0.014)\end{array}$ & $\begin{array}{c}0.007^{* * *} \\
(0.002)\end{array}$ & $\begin{array}{c}0.019 \\
(0.019)\end{array}$ & $\begin{array}{c}0.009 \\
(0.012)\end{array}$ & $\begin{array}{l}-0.000 \\
(0.002)\end{array}$ & $\begin{array}{l}-0.016^{*} \\
(0.009)\end{array}$ & $\begin{array}{l}-0.003 \\
(0.006)\end{array}$ & $\begin{array}{c}-0.003^{\text {*** }} \\
(0.001)\end{array}$ \\
\hline _cons & $\begin{array}{c}0.008 \\
(0.183)\end{array}$ & $\begin{array}{l}1.411^{* * * *} \\
(0.144)\end{array}$ & $\begin{array}{c}0.131^{* * *} \\
(0.020)\end{array}$ & $\begin{array}{l}0.277^{* *} \\
(0.127)\end{array}$ & $\begin{array}{c}1.360^{* * *} \\
(0.077)\end{array}$ & $\begin{array}{c}0.080^{* * *} \\
(0.011)\end{array}$ & $\begin{array}{c}0.096 \\
(0.100)\end{array}$ & $\begin{array}{c}0.836^{* * *} \\
(0.087)\end{array}$ & $\begin{array}{c}0.021^{*} \\
(0.012)\end{array}$ \\
\hline Fixed Effect & Yes & Yes & Yes & Yes & Yes & Yes & Yes & Yes & Yes \\
\hline$N$ & 7276 & 7276 & 7340 & 10774 & 10774 & 11001 & 23123 & 23123 & 23594 \\
\hline $\mathrm{r} 2$ & 0.034 & 0.135 & 0.089 & 0.024 & 0.125 & 0.067 & 0.084 & 0.163 & 0.127 \\
\hline N_clust & 4357 & 4357 & 4413 & 4356 & 4356 & 4439 & 5270 & 5270 & 5383 \\
\hline
\end{tabular}

Standard errors robust to heteroscedasticity and clustering within firm-level are given in parentheses. All variable definitions are as described in Table $1 . *$ Indicates significance at $10 \% ; * *$ Indicates significance at $5 \% ; * * *$ Indicates significance at $1 \%$. 
Table 13: Effects of flexibility during crisis

\begin{tabular}{|c|c|c|c|c|c|c|c|c|c|c|c|c|}
\hline & \multicolumn{12}{|c|}{ Investment 1} \\
\hline & \multicolumn{4}{|c|}{ Pre-Crisis } & \multicolumn{4}{|c|}{ Crisis } & \multicolumn{4}{|c|}{ Post Crisis } \\
\hline & \multicolumn{2}{|c|}{ LCHL } & \multicolumn{2}{|c|}{ HCLL } & \multicolumn{2}{|c|}{ LCHL } & \multicolumn{2}{|c|}{ HCLL } & \multicolumn{2}{|c|}{ LCHL } & \multicolumn{2}{|c|}{ HCLL } \\
\hline & $(1)$ & (2) & (3) & $(4)$ & $(5)$ & (6) & $(7)$ & $(8)$ & $(9)$ & $(10)$ & $(11)$ & $(12)$ \\
\hline MSent & $\begin{array}{c}0.017 \\
(0.198)\end{array}$ & $\begin{array}{c}0.201 \\
(0.298)\end{array}$ & $\begin{array}{l}0.376^{* *} \\
(0.171)\end{array}$ & $\begin{array}{l}0.016^{* *} \\
(0.243)\end{array}$ & $\begin{array}{l}0.179^{* * *} \\
(0.051)\end{array}$ & $\begin{array}{l}0.176^{* *} \\
(0.069)\end{array}$ & $\begin{array}{c}0.003 \\
(0.055)\end{array}$ & $\begin{array}{c}0.081 \\
(0.070)\end{array}$ & $\begin{array}{c}0.907^{* * *} \\
(0.326)\end{array}$ & $\begin{array}{l}0.952^{* * *} \\
(0.352)\end{array}$ & $\begin{array}{l}1.084^{* * *} \\
(0.263)\end{array}$ & $\begin{array}{c}0.993^{* * *} \\
(0.310)\end{array}$ \\
\hline SZ & & $\begin{array}{c}-0.004 \\
(0.064)\end{array}$ & & $\begin{array}{c}0.071 \\
(0.049)\end{array}$ & & $\begin{array}{l}-0.039 \\
(0.062)\end{array}$ & & $\begin{array}{l}-0.057 \\
(0.044)\end{array}$ & & $\begin{array}{c}-0.072^{* * *} \\
(0.023)\end{array}$ & & $\begin{array}{c}-0.071^{\text {*** }} \\
(0.019)\end{array}$ \\
\hline TAN & & $\begin{array}{c}-0.756^{* * *} \\
(0.267)\end{array}$ & & $\begin{array}{c}-1.374^{\text {**** }} \\
(0.280)\end{array}$ & & $\begin{array}{c}-0.620^{* * *} \\
(0.181)\end{array}$ & & $\begin{array}{c}-0.655^{* * *} \\
(0.196)\end{array}$ & & $\begin{array}{c}-0.362^{* * *} \\
(0.102)\end{array}$ & & $\begin{array}{c}-0.241^{\text {**** }} \\
(0.087)\end{array}$ \\
\hline NDTS & & $\begin{array}{l}-1.600^{*} \\
(0.821)\end{array}$ & & $\begin{array}{c}-0.041 \\
(0.456)\end{array}$ & & $\begin{array}{l}-0.996 \\
(1.000)\end{array}$ & & $\begin{array}{c}-2.090^{* * *} \\
(0.695)\end{array}$ & & $\begin{array}{c}-3.036^{* * *} \\
(0.595)\end{array}$ & & $\begin{array}{c}-3.805^{* * *} \\
(0.444)\end{array}$ \\
\hline ROA & & $\begin{array}{c}-0.003 \\
(0.208)\end{array}$ & & $\begin{array}{c}0.087 \\
(0.077)\end{array}$ & & $\begin{array}{c}0.143 \\
(0.129)\end{array}$ & & $\begin{array}{c}0.027 \\
(0.092)\end{array}$ & & $\begin{array}{c}0.107 \\
(0.080)\end{array}$ & & $\begin{array}{c}0.149^{* * *} \\
(0.047)\end{array}$ \\
\hline GR & & $\begin{array}{c}0.003 \\
(0.020)\end{array}$ & & $\begin{array}{l}0.018^{* *} \\
(0.008)\end{array}$ & & $\begin{array}{c}0.002 \\
(0.016)\end{array}$ & & $\begin{array}{l}-0.005 \\
(0.010)\end{array}$ & & $\begin{array}{c}0.002 \\
(0.010)\end{array}$ & & $\begin{array}{c}0.003 \\
(0.005)\end{array}$ \\
\hline EVOL & & $\begin{array}{c}0.045 \\
(0.061)\end{array}$ & & $\begin{array}{c}0.019 \\
(0.051)\end{array}$ & & $\begin{array}{c}0.058 \\
(0.063)\end{array}$ & & $\begin{array}{c}0.004 \\
(0.040)\end{array}$ & & $\begin{array}{c}-0.036 \\
(0.044)\end{array}$ & & $\begin{array}{c}0.004 \\
(0.029)\end{array}$ \\
\hline DIV & & $\begin{array}{l}-0.117 \\
(0.090)\end{array}$ & & $\begin{array}{c}0.092 \\
(0.067)\end{array}$ & & $\begin{array}{c}0.043 \\
(0.036)\end{array}$ & & $\begin{array}{c}0.025 \\
(0.034)\end{array}$ & & $\begin{array}{l}-0.039^{*} \\
(0.024)\end{array}$ & & $\begin{array}{l}0.036^{\text {** }} \\
(0.017)\end{array}$ \\
\hline SYSRISK & & $\begin{array}{c}-0.014 \\
(0.040)\end{array}$ & & $\begin{array}{c}0.021 \\
(0.019)\end{array}$ & & $\begin{array}{l}-0.001 \\
(0.011)\end{array}$ & & $\begin{array}{c}0.009 \\
(0.008)\end{array}$ & & $\begin{array}{c}0.002 \\
(0.010)\end{array}$ & & $\begin{array}{c}0.008 \\
(0.006)\end{array}$ \\
\hline IDIORISK & & $\begin{array}{c}0.012 \\
(0.052)\end{array}$ & & $\begin{array}{c}0.041 \\
(0.036)\end{array}$ & & $\begin{array}{c}-0.009 \\
(0.033)\end{array}$ & & $\begin{array}{c}0.058 \\
(0.039)\end{array}$ & & $\begin{array}{c}-0.022 \\
(0.021)\end{array}$ & & $\begin{array}{c}0.008 \\
(0.016)\end{array}$ \\
\hline _cons & $\begin{array}{c}-0.056 \\
(0.105) \\
\end{array}$ & $\begin{array}{c}0.362 \\
(0.407) \\
\end{array}$ & $\begin{array}{c}-0.382^{* * *} \\
(0.092) \\
\end{array}$ & $\begin{array}{l}-0.403 \\
(0.260) \\
\end{array}$ & $\begin{array}{c}-0.061^{* * *} \\
(0.022) \\
\end{array}$ & $\begin{array}{c}0.304 \\
(0.361) \\
\end{array}$ & $\begin{array}{c}-0.095^{\text {*** }} \\
(0.024) \\
\end{array}$ & $\begin{array}{c}0.266 \\
(0.217) \\
\end{array}$ & $\begin{array}{c}-0.560^{* * *} \\
(0.193) \\
\end{array}$ & $\begin{array}{c}0.109 \\
(0.259) \\
\end{array}$ & $\begin{array}{c}-0.771^{\text {**** }} \\
(0.154)\end{array}$ & $\begin{array}{l}-0.210 \\
(0.215) \\
\end{array}$ \\
\hline Fixed Effect & Yes & Yes & Yes & Yes & Yes & Yes & Yes & Yes & Yes & Yes & Yes & Yes \\
\hline$N$ & 2898 & 1638 & 4408 & 2008 & 3394 & 2647 & 4533 & 3144 & 5365 & 4029 & 10128 & 6863 \\
\hline $\mathrm{r} 2$ & 0.010 & 0.047 & 0.013 & 0.102 & 0.017 & 0.054 & 0.010 & 0.037 & 0.029 & 0.094 & 0.043 & 0.096 \\
\hline N_clust & 1730 & 1168 & 2412 & 1407 & 1940 & 1458 & 2443 & 1652 & 2367 & 1704 & 3463 & 2281 \\
\hline
\end{tabular}

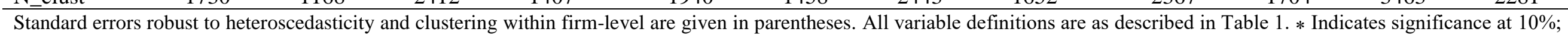
$* *$ Indicates significance at $5 \% ; * * *$ Indicates significance at $1 \%$. 
Table 14: Future profitability under crisis

\begin{tabular}{|c|c|c|c|c|c|c|c|c|c|c|c|c|}
\hline & \multicolumn{12}{|c|}{ Investment 1} \\
\hline & \multicolumn{4}{|c|}{ Pre-Crisis } & \multicolumn{4}{|c|}{ Crisis } & \multicolumn{4}{|c|}{ Post Crisis } \\
\hline & $(1)$ & $(2)$ & (3) & $(4)$ & $(5)$ & (6) & $(7)$ & $(8)$ & (9) & (10) & (11) & (12) \\
\hline MSent & $\begin{array}{c}0.241 \\
(0.078)\end{array}$ & $\begin{array}{c}0.087 \\
(0.103)\end{array}$ & $\begin{array}{c}0.139 \\
(0.081)\end{array}$ & $\begin{array}{c}0.001 \\
(0.115)\end{array}$ & $\begin{array}{l}0.035^{* *} \\
(0.026)\end{array}$ & $\begin{array}{l}0.065^{* *} \\
(0.031)\end{array}$ & $\begin{array}{l}0.031^{* *} \\
(0.026)\end{array}$ & $\begin{array}{c}0.059^{*} \\
(0.031)\end{array}$ & $\begin{array}{c}0.550^{* * *} \\
(0.075)\end{array}$ & $\begin{array}{c}0.296^{* * *} \\
(0.104)\end{array}$ & $\begin{array}{c}0.545^{* * *} \\
(0.077)\end{array}$ & $\begin{array}{c}0.286^{* * *} \\
(0.106)\end{array}$ \\
\hline Profma & $\begin{array}{c}0.002 \\
(0.001)\end{array}$ & $\begin{array}{c}0.000 \\
(0.002)\end{array}$ & & & $\begin{array}{c}-0.001 \\
(0.001)\end{array}$ & $\begin{array}{c}0.001 \\
(0.002)\end{array}$ & & & $\begin{array}{c}0.000 \\
(0.001)\end{array}$ & $\begin{array}{c}0.001 \\
(0.001)\end{array}$ & & \\
\hline Profma $_{t+1}$ & $\begin{array}{c}0.001 \\
(0.001)\end{array}$ & $\begin{array}{l}-0.002 \\
(0.002)\end{array}$ & & & $\begin{array}{l}-0.002 \\
(0.002)\end{array}$ & $\begin{array}{l}-0.001 \\
(0.002)\end{array}$ & & & $\begin{array}{l}-0.001 \\
(0.001)\end{array}$ & $\begin{array}{l}-0.002 \\
(0.001)\end{array}$ & & \\
\hline Profma $_{t+2}$ & $\begin{array}{c}0.000 \\
(0.001)\end{array}$ & $\begin{array}{l}-0.003^{*} \\
(0.002)\end{array}$ & & & $\begin{array}{c}-0.001 \\
(0.001)\end{array}$ & $\begin{array}{c}0.001 \\
(0.001)\end{array}$ & & & $\begin{array}{c}-0.000 \\
(0.001)\end{array}$ & $\begin{array}{c}-0.001 \\
(0.002)\end{array}$ & & \\
\hline Profma $t_{t+3}$ & $\begin{array}{l}-0.001 \\
(0.001)\end{array}$ & $\begin{array}{c}0.001 \\
(0.002)\end{array}$ & & & $\begin{array}{l}-0.002 \\
(0.001)\end{array}$ & $\begin{array}{l}-0.002 \\
(0.002)\end{array}$ & & & $\begin{array}{l}-0.000 \\
(0.001)\end{array}$ & $\begin{array}{c}-0.002^{* *} \\
(0.001)\end{array}$ & & \\
\hline ROA & & & $\begin{array}{c}-0.072^{* * *} \\
(0.018)\end{array}$ & $\begin{array}{c}-0.078 \\
(0.055)\end{array}$ & & & $\begin{array}{c}0.010 \\
(0.022)\end{array}$ & $\begin{array}{c}0.026 \\
(0.040)\end{array}$ & & & $\begin{array}{l}0.006^{* *} \\
(0.003)\end{array}$ & $\begin{array}{c}0.036^{\text {**** }} \\
(0.014)\end{array}$ \\
\hline $\mathrm{ROA}_{t+1}$ & & & $\begin{array}{c}-0.033^{* * *} \\
(0.009)\end{array}$ & $\begin{array}{c}0.022 \\
(0.045)\end{array}$ & & & $\begin{array}{c}-0.031^{\text {** }} \\
(0.015)\end{array}$ & $\begin{array}{l}-0.028 \\
(0.019)\end{array}$ & & & $\begin{array}{c}-0.011^{\text {**** }} \\
(0.002)\end{array}$ & $\begin{array}{l}-0.025 \\
(0.016)\end{array}$ \\
\hline $\mathrm{ROA}_{\mathrm{t}+2}$ & & & $\begin{array}{c}-0.040^{* * *} \\
(0.011)\end{array}$ & $\begin{array}{l}-0.040 \\
(0.043)\end{array}$ & & & $\begin{array}{l}-0.000 \\
(0.001)\end{array}$ & $\begin{array}{c}0.007 \\
(0.017)\end{array}$ & & & $\begin{array}{l}-0.000 \\
(0.001)\end{array}$ & $\begin{array}{l}-0.010 \\
(0.009)\end{array}$ \\
\hline $\mathrm{ROA}_{t+3}$ & & & $\begin{array}{c}-0.004 \\
(0.011)\end{array}$ & $\begin{array}{c}0.055 \\
(0.058)\end{array}$ & & & $\begin{array}{c}0.000 \\
(0.001)\end{array}$ & $\begin{array}{c}-0.003 \\
(0.012)\end{array}$ & & & $\begin{array}{c}0.001 \\
(0.001)\end{array}$ & $\begin{array}{c}0.001 \\
(0.001)\end{array}$ \\
\hline _cons & $\begin{array}{l}-0.215^{\text {**** }} \\
(0.042)\end{array}$ & $\begin{array}{c}0.037 \\
(0.220)\end{array}$ & $\begin{array}{c}-0.157^{* * *} \\
(0.044)\end{array}$ & $\begin{array}{c}0.099 \\
(0.237)\end{array}$ & $\begin{array}{c}-0.044^{\text {*** }} \\
(0.011)\end{array}$ & $\begin{array}{c}0.290^{*} \\
(0.157)\end{array}$ & $\begin{array}{c}-0.042^{\text {*** }} \\
(0.012)\end{array}$ & $\begin{array}{c}0.285^{*} \\
(0.158)\end{array}$ & $\begin{array}{l}-0.339^{\text {**** }} \\
(0.042)\end{array}$ & $\begin{array}{l}0.283^{* *} \\
(0.124)\end{array}$ & $\begin{array}{c}-0.338^{* * *} \\
(0.044)\end{array}$ & $\begin{array}{l}0.297^{* *} \\
(0.126)\end{array}$ \\
\hline Fixed Effect & Yes & Yes & Yes & Yes & Yes & Yes & Yes & Yes & Yes & Yes & Yes & Yes \\
\hline Other Controls & No & Yes & No & Yes & No & Yes & No & Yes & No & Yes & No & Yes \\
\hline$N$ & 10495 & 5412 & 9647 & 5273 & 10310 & 8076 & 9509 & 7877 & 13810 & 10215 & 12875 & 10016 \\
\hline $\mathrm{r} 2$ & 0.005 & 0.035 & 0.009 & 0.039 & 0.003 & 0.030 & 0.004 & 0.032 & 0.008 & 0.040 & 0.012 & 0.045 \\
\hline N_clust & 4278 & 3211 & 3866 & 3113 & 4146 & 3126 & 3823 & 3028 & 4563 & 3240 & 4150 & 3138 \\
\hline
\end{tabular}

Standard errors robust to heteroscedasticity and clustering within firm-level are given in parentheses. All variable definitions are as described in Table $1 . *$ Indicates significance at $10 \% ; * \star$ Indicates significance at $5 \% ; * \star \star$ Indicates significance at $1 \%$. 